\title{
13. MINERALOGIC AND STABLE ISOTOPE RECORD OF POLYPHASE ALTERATION OF UPPER CRUSTAL GABBROS OF THE EAST PACIFIC RISE (HESS DEEP, SITE 894) ${ }^{1}$
}

\author{
G.L. Früh-Green, ${ }^{2}$ A. Plas, ${ }^{2}$ and L.N. Dell'Angelo ${ }^{2}$
}

\begin{abstract}
Leg 147 of the Ocean Drilling Program recovered sections of the East Pacific Rise lower crust and shallow mantle $(\approx 1 \mathrm{Ma})$, tectonically exposed at the western end of the Cocos-Nazca propagator at the Hess Deep Rift Valley. At Site 894, variably metamorphosed, isotropic gabbros and gabbronorites from the upper part of the plutonic section were recovered. In this study, we present petrologic and stable isotope data that document a complex polyphase history of fluid infiltration, metamorphism, and deformation from late magmatic activity through upper amphibolite facies to zeolite facies conditions. Alteration occurred through several stages of fracturing and fluid infiltration during progressive transport of the oceanic crust away from the axis of the East Pacific Rise and ultimate intersection with the Cocos-Nazca propagator. Alteration was controlled by fracture permeabilities, grain geometries, and the chemical composition of progressive pulses of hydrothermal fluids. Early, near-axis high temperature $\left(>500^{\circ} \mathrm{C}\right)$ fluid infiltration in microveins and along grain boundaries produced amphibolite-facies mineral assemblages. Subsequent off-axis cooling and Cocos-Nazca-related uplift and faulting enhanced fluid penetration, resulting in variable overprinting under greenschist to zeolite facies conditions in association with discrete veins and local cataclastic shear zones.

Oxygen isotope ratios of amphibole separates are depleted in ${ }^{18} \mathrm{O}$ relative to unaltered gabbro compositions and are consistent with high temperature exchange with aqueous fluids. Plagioclase compositions form two groups: a high temperature altered group $\left(\delta^{18} \mathrm{O}\right.$ between $3.0 \%$ and $6.3 \%$ ); and a group with $\delta^{18} \mathrm{O}$ between $8.3 \%$ and $10.2 \%$, indicative of local lower temperature $\left(150^{\circ}-250^{\circ} \mathrm{C}\right)$ overprinting associated with discrete veining. $\mathrm{D} / \mathrm{H}$ ratios of amphibole suggest two components in the early hydrothermal fluids: an altered seawater component $(\delta \mathrm{D} \approx 0 \%$ ) and a mixed magmatic-derived/altered seawater component $(\delta \mathrm{D}-30 \%$ to $-20 \%$ ) . These data, combined with microstructural data, suggest that penetration of seawater at high temperatures $\left(>500^{\circ} \mathrm{C}\right)$, possibly mixing with $\mathrm{CO}_{2}$-rich magmatic volatiles, resulted in a low ${ }^{18} \mathrm{O}$ sequence of upper-amphibolite facies oceanic lithosphere at an early stage in the spreading history of the EPR. Fluid mixing at magma chamber/oceanic crust boundaries and fracture-controlled, high-temperature metamorphism may be characteristic of alteration processes at this fast-spreading ridge environment.
\end{abstract}

\section{INTRODUCTION}

In recent years, new models of the interaction between magmatic, tectonic, and hydrothermal processes at mid-ocean ridges have been made through detailed oceanographic surveys and petrologic studies of volcanic and plutonic rocks recovered from the ocean floor. These models predict a segmented ridge system with discontinuous magma chambers and intermittent magma production at regularly spaced intervals (e.g., Whitehead et al., 1984; Crane, 1985; MacDonald, 1987; Sinton and Detrick, 1992). The recent studies and models suggest that the structure and geochemistry of the oceanic crust may be heterogeneous on a small scale and that the internal stratigraphy depends greatly on spreading rate, rate of magma supply, and phases of amagmatic and magmatic extension. In addition, the recovery of hydrothermally altered oceanic rocks as well as the discovery of high-temperature vents along spreading centers indicates that submarine hydrothermal systems play an important role in crustal evolution at mid-ocean ridge systems. Fluid circulation is not only an important process in the transport of heat from young oceanic crust, but seawater-rock reactions also play a major role in buffering the isotopic and chemical compositions of seawater (e.g, Gregory and Taylor, 1981; Thompson, 1983; Von Damm et al., 1985; Alt et al., 1986b; Muehlenbachs, 1986). There is no doubt that magmatism is of fundamental importance in providing thermal energy for circulating hydrothermal fluids; however, the interaction at the magma chamber-crust

'Mével, C., Gillis, K.M., Allan, J.F., and Meyer, P.S. (Eds.), 1996. Proc. ODP, Sci. Results, 147: College Station, TX (Ocean Drilling Program).

${ }^{2}$ Department of Earth Sciences, ETH-Zürich, CH-8092 Zürich, Switzerland. boundary and the degree to which magmatic volatiles contribute to the isotopic and chemical composition of upwelling fluids remains poorly constrained. Although much information has been gained toward understanding these ocean floor processes, our knowledge of magma generation, melt migration and related hydrothermal alteration is still to a large extent limited to studies of ophiolites and to samples recovered with submersibles and dredging. It is thus essential to employ deep drilling techniques, promoted by the Ocean Drilling Program (ODP), to recover continuous in situ sections of the oceanic lower crust and upper mantle.

The spectacular recovery of lower crustal rocks at Hole 735B during ODP Leg 118 to the Atlantis II Fracture Zone along the Southwest Indian Ridge (SWIR) has had a significant impact on our understanding of processes of magmatism, tectonism, and seawater penetration at slow-spreading ridges (Von Herzen et al., 1991). Petrologic and geochemical studies of the gabbroic rocks recovered at Site 735B have substantiated the view that the lower crust at slow-spreading ridges is formed by small, discrete magma bodies with complex intrusive relations in regions of low magma supply. Lithologic relationships indicate that the stratigraphy of this plutonic section was modified by syntectonic differentiation processes, whereby intercumulus melt was squeezed from partially molten gabbro and localized along ductile shear zones (Dick et al., 1991). These ductile shear zones within the gabbroic sequence also acted as conduits of enhanced permeability allowing early penetration of seawater into the lower crust and resulting in localized high-temperature metamorphism (Cannat et al., 1991; Dick et al., 1991; Stakes et al., 1991).

Leg 147 represents the first successful employment of an offset drilling strategy in which multiple holes were cored at the Hess Deep Rift Valley to reconstruct a composite section of the oceanic crust 
generated at a fast-spreading ridge. During Leg 147 continuous sections of crustal gabbroic rocks and shallow mantle harzburgite, dunite, and intercalated gabbroic rocks generated at the East Pacific Rise (EPR) were recovered for the first time (Shipboard Scientific Party, 1993a, 1993b). Two sites were drilled to gain an understanding of the igneous, metamorphic and structural evolution of the EPR lower crust (Site 894) and upper mantle (Site 895) and to better constrain magmatic, hydrothermal, and tectonic processes in an environment with a high rate of magma supply.

\section{Tectonic Setting and Geologic Overview}

Hess Deep is the deepest part ( $>5400$ meters below seafloor [mbsf]) of a tectonically complex, westward-propagating oceanic rift valley located near the junction of the Pacific, Nazca, and Cocos Plates west of the Galapagos Islands (Fig. 1). This rift valley has formed as the result of deep faulting associated with the westward propagation of the east-west-trending Cocos-Nazca spreading center that is opening up the eastern flank of young oceanic crust $(0.5-1 \mathrm{Ma})$ created at the fast-spreading equatorial EPR (Lonsdale, 1988; Francheteau et al., 1990). A major intra-rift ridge with a flattened crest and an oval dome shape occurs between the Hess Deep and the northern scarp that bounds the valley. The intra-rift ridge, approximately $8 \mathrm{~km}$ wide and $25 \mathrm{~km}$ long, extends eastward and overlaps the western end of the Cocos-Nazca spreading center.

The scarps that bound the Hess Deep Rift Valley and the intra-rift ridge were investigated during two submersible cruises. In 1988, a Nautile dive program investigated the floor and walls of the rift valley (Francheteau et al., 1990; Francheteau et al., 1992), and in 1989 an Alvin dive program was conducted along the rift valley walls (Karson et al., 1992). The results of these dive programs showed that a complete, relatively fresh crustal section, consisting of volcanics, sheeted dikes, and minor gabbros, is exposed along the scarps that bound the rift valley. Similar, but more dismembered sections of the EPR oceanic crust, including lavas, dikes, gabbros, and peridotites, are exposed on the floor of the Hess Deep Rift Valley and along the intra-rift ridge (Francheteau et al., 1990, Hekinian et al., 1993). This area was investigated in detail and sampled by the Nautile dive program during two north-south-trending transects, centered at the western $(3040 \mathrm{~m})$ and eastern (2900) summits of the intra-rift ridge (see fig. 2 in Francheteau et al., 1990). The distribution of rock types along the western and eastern transects indicates a complex, tectonically dismembered structure of the Hess Deep with no lateral continuity in rock type along the intra-rift ridge. Observations made during the recent dive campaigns suggest that the western end of the intra-rift ridge is made up predominantly of massive blocks of gabbros, whereas the eastern end is composed of upper crustal rocks, dolerites, and basalts. Peridotites were mainly found near the base of the southern flank of the intra-ridge.

Two alternative rifting models have been proposed for the formation of the Hess Deep Rift Valley and the emplacement of deep crustal rocks at shallow levels in the oceanic crust (see fig. 6 in Francheteau et al., 1990). The first model emphasizes the overall symmetry of the rift valley and invokes vertical movements through isostatic readjustment and diapiric uplift of serpentinized mantle. The second model proposes a mechanism of low-angle detachment to expose and entrain upper mantle and lower crustal rocks. This model implies that extension was accommodated by rotation of large crustal blocks along listric normal faults similar to those in rifted continental lithosphere and recently postulated for slow-spreading ridges and the Galicia margin (Karson et al., 1987; Boillot et al., 1980).

Taking advantage of this tectonic exposure, Leg 147 successfully cored two sites and recovered continuous sections of lower crust and upper mantle that were created at the EPR. The first site, Site 894, is located near the summit at the western end of the intra-rift ridge in water depths between 3023 and $3044 \mathrm{~m}$, close to the site where gabbroic rocks were recovered during the 1988 Nautile dive campaign.

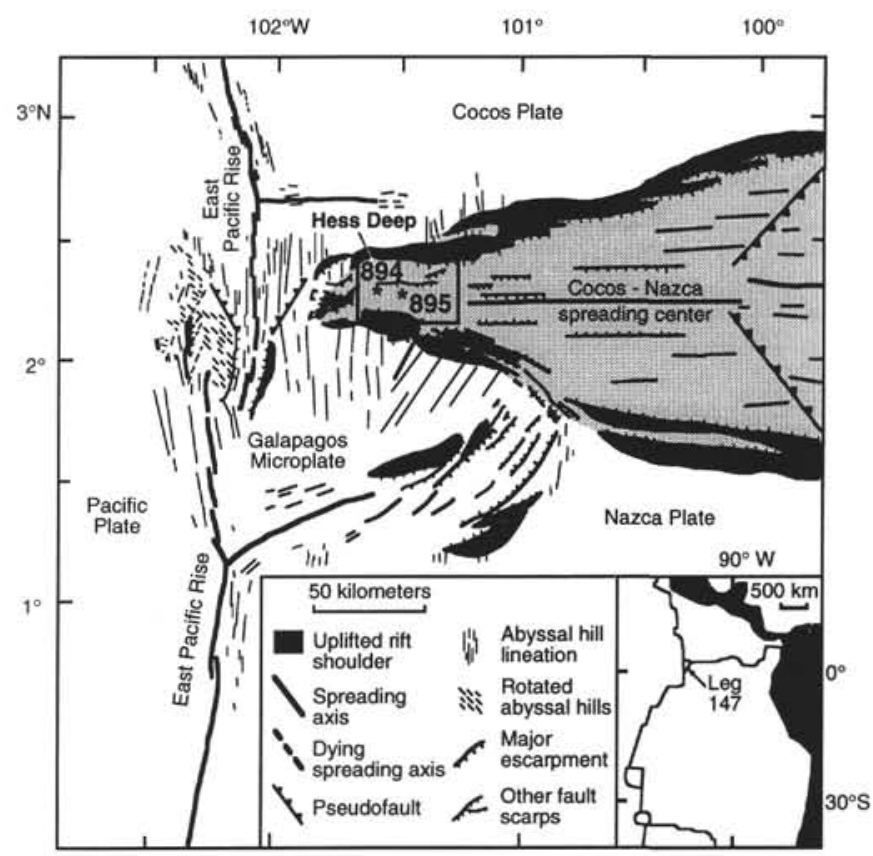

Figure 1. Tectonic location of Hess Deep at the western end of the CocosNazca spreading center. After Lonsdale (1988), Francheteau et al. (1990), and Karson et al. (1992).

Seven holes were drilled, one of which (Hole 894G) penetrated a total of $154 \mathrm{mbsf}$ and recovered approximately $46 \mathrm{~m}$ of olivine gabbro, olivine gabbronorites, gabbro, gabbronorite, oxide gabbronorite, and oxide gabbro. This sequences lacks well-developed modal layering and shows a large variation in grain size and texture, similar to upper level plutonic sections in many ophiolites (Gillis, Mével, Allan, et al., 1993). A spectacular, steeply dipping magmatic foliation, defined by the alignment of tabular plagioclase crystals, occurs in the lower parts of the sections in Hole $894 \mathrm{G}$. This foliation has a mean dip of $75^{\circ}$ (with a standard deviation of $13^{\circ}$ ) and, when restored with reference to core paleomagnetic data, shows a nearly north-south trend that is approximately parallel to the strike of the EPR spreading axis (Gillis, Mével, Allan, et al., 1993; MacLeod et al., 1993; Célérier et al., this volume). One important observation in the gabbroic section is the occurrence of dikelets or vein-like patches of coarsegrained to pegmatitic gabbronorites that postdate foliated finegrained gabbro. These contacts and the absence of orthopyroxene in the foliated gabbro suggest that segregations of melt were locally squeezed out of the foliated host and that accumulation and flow of interstitial melt is a significant process in the upper part of magma chambers.

In this study, petrologic and stable isotope data are presented to characterize the subsolidus (metamorphic /hydrothermal) alteration history of the gabbroic sequence at Site 894 and to investigate the relationship between deformation and fluid-rock interaction during the evolution of the oceanic crust at Hess Deep. In particular, stable isotope ratios furnish important information on the temperatures of alteration and the extent, mechanisms, and relative timing of seawater penetration in the oceanic lower crust. Emphasis has been placed on studying the effects of later low temperature deformation on the alteration history of the gabbroic section. These data, combined with petrology and phase chemistry provide new constraints from a fastspreading environment on the general models of hydrothermal alteration and oxygen isotope exchange in the oceanic crust and allow a comparison with metamorphic/hydrothermal processes documented in oceanic gabbros at Hole 735B at the slow-spreading SWIR (Dick et al., 1991; Kempton et al., 1991; Stakes et al., 1991). 


\section{ANALYTICAL METHODS}

A set of 37 polished thin sections was used for petrographic descriptions and microprobe analyses. A bias in sampling was made toward samples that were veined or deformed in order to better characterize the low temperature alteration history of the Site 894 gabbros. This study provides complementary data to the work of Lécuyer and Gruau (this volume), who document the isotopic characteristics of relatively fresh, undeformed samples. Mineral chemistries were determined using a Cameca SX50 electron microprobe with natural minerals for standards and a standard correction program for oxides and silicates. The operating conditions were $15 \mathrm{kV}$ accelerating voltage, $20 \mathrm{nA}$ sample current, 20-30 s/element counting time and a 1$10 \mu \mathrm{m}$ spot size.

Vein mineralogies and fine-grained alteration products separated from bulk powdered samples were determined by X-ray diffraction (XRD) analysis on a Scintag X-ray diffractometer. Samples were run between $2^{\circ}$ and $65^{\circ} 2 \theta, 40 \mathrm{kV} / 20 \mathrm{~mA}$, using CuK $\alpha$ radiation, and a scan speed of $2 \% \mathrm{~min}$. Clay-size fractions $(<2 \mu \mathrm{m})$ were separated from bulk samples and veins by settling in a water column. Clay mineral assemblages were determined by XRD analysis using a scan speed of $1 \% \mathrm{~min}$; Smectite and mixed-layered clays were identified by comparing diffraction patterns of air-dried and ethylene glycol-solvated preparations, with quartz as an internal standard. One representative vein sample was examined under the scanning electron microscope (SEM), operating at $15 \mathrm{kV}$ and equipped with qualitative chemical analysis capabilities. The microstructures and mineralogy of several cataclasite zones have been further analyzed using transmission electron microscopy (TEM). Epoxy-impregnated specimens were thin-sectioned, mounted on copper grids, and ion-milled. Samples were examined in the TEM operating at $200 \mathrm{keV}$.

Analyses of hydrogen, oxygen, and carbon isotopes were conducted on mineral separates and vein material. Mineral separates were obtained from crushed, sieved, and ultrasonically cleaned samples using a Frantz magnetic separator and standard heavy liquid techniques. The mineral separates (excluding clays) were further rinsed in $3 \mathrm{M} \mathrm{HCl}$ to remove carbonates and surface contamination and rinsed in distilled water prior to hand picking. Purity of the separates was determined by XRD, and in most cases, is better than $95 \%$.

Carbon and oxygen isotope ratios of carbonates were determined on $\mathrm{CO}_{2}$ gas liberated by reaction with phosphoric acid (McCrea, 1950). Oxygen was liberated from silicate samples by reaction with $\mathrm{ClF}_{3}$ at $600^{\circ} \mathrm{C}$ (Borthwick and Harmon, 1982) and converted to $\mathrm{CO}_{2}$ by reaction with heated carbon. For hydrogen isotope analysis, hydrous mineral separates were dried at $120^{\circ} \mathrm{C}$ under vacuum overnight, then heated in a vacuum to $>1100^{\circ} \mathrm{C}$ to liberate $\mathrm{H}_{2}$ and $\mathrm{H}_{2} \mathrm{O}$. Molecular hydrogen was converted to water by reaction with copper oxide. The resulting total water was quantitatively converted to hydrogen by reaction with zinc. The isotopic ratios of all samples were determined at the ETH-Zürich by conventional mass spectrometric analysis on VG OPTIMA and VG PRISM dual inlet mass spectrometers, calibrated against Vienna-Standard Mean Ocean Water (VSMOW), Standard Light Antarctic Precipitation (SLAP), and Greenland Ice Sheet Precipitation (GISP). The ratios are reported in standard $\delta$-notation in per mil $(\% o)$ relative to the Pee Dee Belemnite (PDB) isotopic standard for carbon and relative to V-SMOW for oxygen and hydrogen. During the period from June 1993 to June 1994, the international quartz standard NBS-28 yielded a value of $9.57 \%$ with a 1 sigma standard deviation of $0.25 \%$. An internal laboratory standard, calibrated against NBS-30 with a value of $-65 \%$, was used for hydrogen isotope analyses. Repeat measurements of individual samples gave an overall reproducibility of $\pm 0.1 \%$ c for carbon isotope ratios, $\pm 0.2 \%$ or oxygen isotope ratios and $\pm 1 \%$ for hydrogen isotope ratios. Repeat measurements of different grain-size fractions from the same mineral yielded no significant variations.

\section{MINERALOGIC CONSTRAINTS ON HYDROTHERMAL ALTERATION AND DEFORMATION}

Of the seven holes drilled at Site 894 , significant recovery of igneous rocks was obtained in Holes $894 \mathrm{~F}$ and $894 \mathrm{G}$. Fracturing and the local development of cataclastic shear zones is predominant in Hole $894 \mathrm{~F}$ (cored to a total depth of $25.7 \mathrm{mbsf}$ ) and the upper $38 \mathrm{mbsf}$ of Hole $894 \mathrm{G}$. Although the uppermost $18.6 \mathrm{mbsf}$ of Hole $894 \mathrm{G}$ were not cored, the close proximity of the two holes (18 m apart) and the similarity in recovered lithologies allows a continuous stratigraphic section to be inferred. Hole $894 \mathrm{G}$ penetrated a total of $154 \mathrm{mbsf}$ and recovered approximately $46 \mathrm{~m}$ of heterogeneously altered and deformed varitextured olivine gabbro, olivine gabbronorites, gabbro, gabbronorite, oxide gabbronorite, and oxide gabbro, with minor basalts. At least $80 \%$ of the rocks recovered at Site 894 are moderately altered to greenschist to upper amphibolite-facies mineral assemblages. The percentage of alteration increases with increasing grain size with no correlation with depth below the seafloor. Upper amphibolite-facies mineral assemblages define the earliest alteration and include hornblenditic amphibole, secondary clinopyroxene, calcic plagioclase, magnetite, and ilmenite. These minerals are overgrown by lower amphibolite- to greenschist-facies assemblages dominated by actinolite, sodic plagioclase, and rare chlorite. The latest alteration phases include albitic plagioclase, zeolite, and clay after plagioclase and smectite after clinopyroxene, orthopyroxene and olivine. Overprinting of the early higher temperature assemblages is associated with macroscopic veins occurring through the section and with local cataclastic zones at shallow depths (see also Gillis, Mével, Allan, et al., 1993; Manning, 1993; MacLeod et al., 1993). The following section describes the petrology and metamorphic evolution of the gabbroic rocks recovered in Holes $894 \mathrm{~F}$ and $894 \mathrm{G}$. These data, together with stable isotope ratios, provide evidence for a complex, polyphase history of interaction between magmatic, hydrothermal, and low temperature deformational processes.

\section{High-temperature Static Metamorphism}

The gabbroic section at Site 894 is characterized by a large variation in grain size, modal composition, and degree of subsolidus alteration and deformation. Static alteration is dominant, producing pseudomorph textures after the primary phases, with multiple phases of overprinting associated with discrete veining events (see also Gillis, this volume; Kelley and Malpas, this volume; Manning and MacLeod, this volume).

The earliest phase of alteration in the Site 894 gabbroic rocks is defined by exsolution in pyroxene and the formation of secondary clinopyroxene, secondary anorthitic plagioclase, ilmenite, magnetite, and hornblende. These phases occur primarily along grain boundaries of the primary phases or in discontinuous microveins. Alteration of clinopyroxene is high to pervasive throughout the section and typically results in turbid dark grains with complex, pseudomorphic replacement textures. The earliest phase of clinopyroxene alteration is characterized by exsolution of orthopyroxene and the formation of secondary clinopyroxene, ilmenite, magnetite, and multiple generations of $\mathrm{Ca}-\mathrm{Al}$ amphibole (PI. 1, Figs. 1 through 3). Rare brown amphibole forms micron-sized anhedral patches in the center of the pseudomorphed grains, grading into fine-grained, pleochroic brown to green, fibrous mats of amphibole \pm secondary clinopyroxene as alteration progresses. Fine-grained, grass-green to blue-green fibrous actinolitic amphibole commonly forms thin, irregular rims around pervasively altered clinopyroxene or occurs as irregularly shaped patches in the pseudomorphed grains (PI. 1, Fig. 3). The turbid appearance of the altered grains results from very fine-grained $(<5 \mu \mathrm{m})$ inclusions of secondary oxides. 
Replacement of primary clinopyroxene by secondary clinopyroxene is common throughout the gabbroic section, and varies from rare fine-grained dusty patches irregularly distributed throughout the primary clinopyroxene to well-developed, coarse-grained, optically continuous, translucent to pale green, anhedral crystals. Secondary clinopyroxene is particularly abundant in the coarse-grained to pegmatitic gabbronorite-rich zones, associated with euhedral to subhedral apatite, zircon, and sphene replacing ilmenite (e.g., in Samples 147-894G-9R-2 [Piece 3], 147-894G-9R-3 [Pieces 4 and 5A], and 147-894G-17R-1 [Pieces 1 and 6]). In these coarse-grained zones, primary clinopyroxene grains are either altered to or associated with: (1) dark brown to dark green pleochroic amphibole, locally intergrown with granular secondary clinopyroxene and clear anorthitic plagioclase (Pl. 1, Fig. 1); (2) subhedral, coarse-grained individual amphibole grains and aggregates of bladed amphibole (possibly of magmatic origin) that exhibit a well-developed cleavage and a pronounced yellow-green to dark green or blue-green pleochroism (Pl. 1, Fig. 1); and (3) a characteristic zoned replacement by clear amphibole with irregularly shaped dark brown cores and yellow-green to dark green or blue-green, inclusion-rich rims. It is difficult to determine the origin of the very coarse-grained (up to $10 \mathrm{~mm}$ long) clusters of amphibole. These are invariably associated with zircon and apatite which appear to be primary late magmatic (deuteric?) phases. However, the close association with secondary hydrothermal clinopyroxene also suggests a high-temperature hydrothermal origin. Replacement of clinopyroxene by amphibole in all lithologies is commonly associated with a pervasive, anastomosing network of amphibole-filled microveins and millimeter-wide veins that crosscut the primary grains and follow grain boundaries. Electron microprobe analysis indicate that the magmatic clinopyroxenes are siallitic in compositions with variable but relatively low $\mathrm{Ti}$ - and $\mathrm{Cr}$-contents, whereas, the secondary clinopyroxenes are enriched in $\mathrm{Ca}$ and $\mathrm{Mg}$ relative to the primary compositions (see also Gillis, this volume).

Electron microprobe analyses of the $\mathrm{Ca}-\mathrm{Al}$ amphiboles pseudomorphing clinopyroxene indicate a continuous range of compositions from magnesio-hornblende through actinolitic hornblende to actinolite (amphibole nomenclature after Leake [1978], modified by Hawthorne [1983]). The compositions are characterized by a variation in $\mathrm{Al}^{\mathrm{IV}}$ from 0.12 to 1.50 , with a range in edenite substitutions $(\mathrm{Na}(\mathrm{A})$ $+\mathrm{K}$ ) from 0.03 to 0.53 (Fig. $2 \mathrm{~A}$ ). Tschermaks substitutions (calculated as $\mathrm{Al}^{\mathrm{VI}}+\mathrm{Cr}+\mathrm{Fe}^{3+}+2 \mathrm{Ti}$ ) show linear variations with the ratio of $\mathrm{Mg}$ to total $\mathrm{Fe}\left[\mathrm{X}_{\mathrm{Mg}}=\mathrm{Mg} /\left(\mathrm{Mg}+\mathrm{Fe}_{\text {total }}\right)\right]$, as shown in Figure $2 \mathrm{~B}$. This trend, together with nearly linear correlations of decreasing aluminum with decreasing $\mathrm{Na}$ in the A-site and increasing $\mathrm{X}_{\mathrm{Mg}}$, reflect progressive crystallization from upper amphibolite-facies to transitional greenschist facies condition (see also Gillis, this volume; Manning, 1993). Profiles measured across individual amphibole grains and veins showed a large range in compositions, which suggests that amphibole growth was continuous over a range of high temperatures. On the basis of pyroxene thermometry and phase equilibria arguments, Manning (1993) estimated temperatures of $650^{\circ}-800^{\circ} \mathrm{C}$ for the early high-temperature phase of metamorphism in the Site 894 gabbros.

In samples devoid of distinct macroscopic chlorite-bearing veins, plagioclase is typically the least altered of the primary phases and exhibits well-developed polysynthetic twinning and complex zoning. The compositions of magmatic plagioclase analyzed in this study lie within a range of approximately 50 to $60 \mathrm{~mol} \%$ anorthite, with smaller variations within individual samples. Distinctly more Na-rich compositions in altered plagioclase grains are associated with later chlorite-prehnite veining (see below).

Alteration of orthopyroxene and olivine is typically heterogeneous in the Site 894 gabbros and records a continuous alteration history from amphibolite to zeolite facies conditions. Orthopyroxene is typically turbid in thin section and altered to fine-grained, fibrous pale green amphibole with rare talc and serpentine. The orthopyrox-

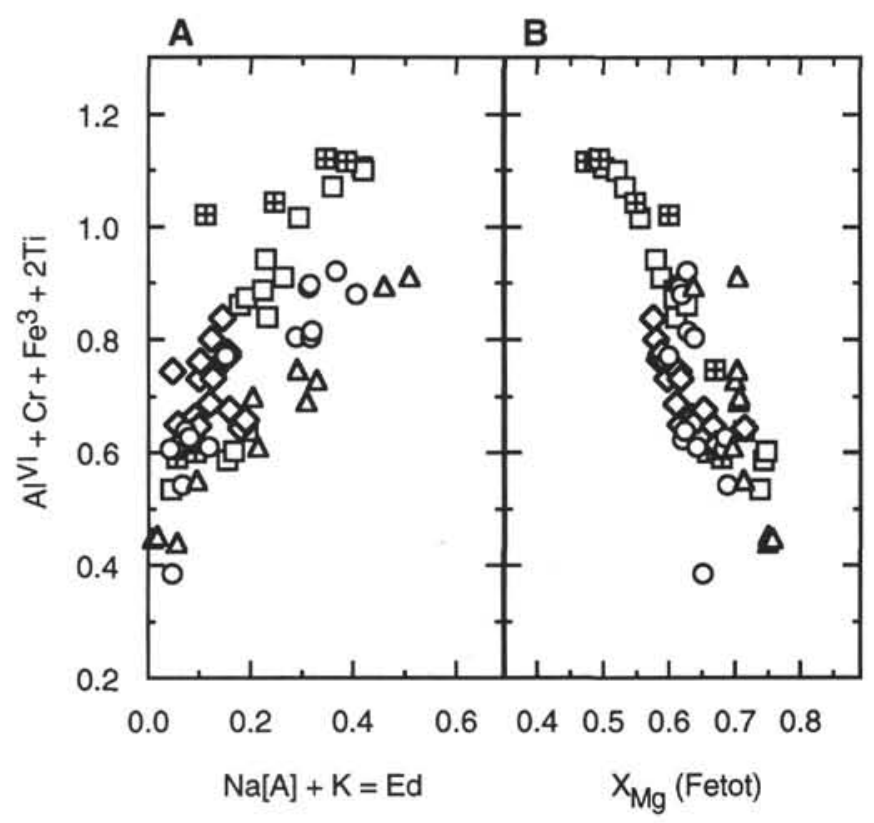

Figure 2. Variations in Tschermaks substitutions (calculated as $\mathrm{Al}^{\mathrm{VI}}+\mathrm{Cr}+$ $\left.\mathrm{Fe}^{3+}+2 \mathrm{Ti}\right)(\mathbf{A})$ as a function of edenite substitution $(\mathrm{Na}(\mathrm{A})+\mathrm{K})$ and $(\mathbf{B})$ as a function of ratio of $\mathrm{Mg}$ to total $\mathrm{Fe}\left[=\mathrm{Mg} /\left(\mathrm{Mg}+\mathrm{Fe}_{\text {total }}\right)\right]$. Triangles = cataclastic gabbros in Hole 894F; squares = amphibolite-facies metamorphic gabbros with amphibole veins (divided squares) in Hole 894F; circles = coarse-grained gabbronorites (with evidence for deuteric alteration) in Hole 894G; diamonds = medium-grained gabbronorites with chlorite-prehnite veins in Hole $894 \mathrm{G}$.

ene grains are commonly cut by magnetite-filled microfractures. $\mathrm{Al}$ teration of olivine is characterized by complex, heterogeneous coronitic replacement textures composed of amphibole, clays, iddingsite, talc, carbonate, magnetite, and pyrite. Fibrous amphibole is the dominant alteration phase in olivine grains that are completely enclosed by orthopyroxene. At contacts to plagioclase, pale green fibrous chlorite with anomalous blue-brown interference colors form the outermost rim of the olivine pseudomorphs. Fine-grained magnetite commonly fill crosscutting microfractures or form thin rims along the original grain boundaries of olivine and orthopyroxene. Compositions of the relict olivines are relatively constant downhole, ranging between 67 and $72 \mathrm{~mol} \%$ forsterite.

\section{Low-temperature Alteration and Brittle Deformation}

Variable overprinting of the high-temperature metamorphic phases related to progressive fracturing and fluid infiltration under greenschist facies to zeolite facies conditions led to the formation of discrete chlorite-prehnite-clay veins and concomitant wall-rock alteration to actinolite, Na-rich plagioclase, prehnite, chlorite, epidote, and clays (see also Gillis, Mével, Allan, et al., 1993). This lower temperature phase of overprinting is particularly reflected in the alteration of magmatic plagioclase. Plagioclase alteration is patchy and becomes most pronounced in alteration halos adjacent to chloriteprehnite veins (see below), resulting in a chalky white appearance in hand sample (Fig. 3). In zones of dense veining, the primary plagioclase grains are pervasively replaced by secondary albitic plagioclase (up to $\mathrm{An}_{15}$ ), clays, and zeolites, giving the grains a turbid, dusty appearance. Secondary albitic plagioclase, or more rarely K-feldspar, also form microveinlets and discontinuous bands that crosscut and rim the original plagioclase grains. Replacement of plagioclase by epidote is related to macroscopic veins with prehnite + chlorite + epi- 


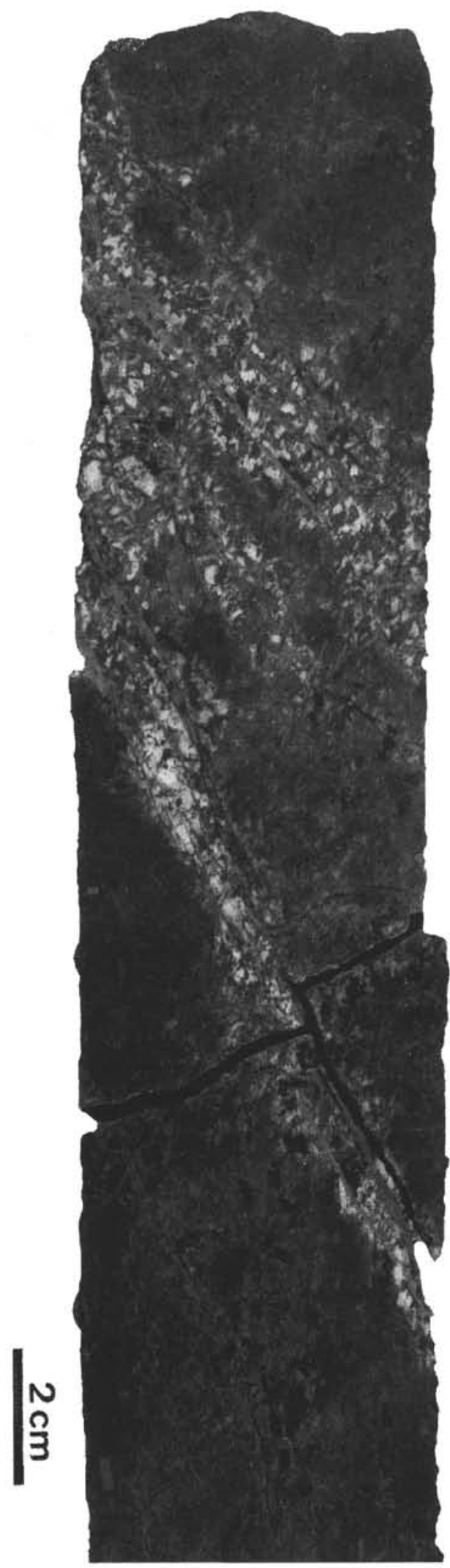

Figure 3. Core photograph of extensive wall-rock alteration associated with dense chlorite/prehnite veining. Alteration is dominated by the replacement of plagioclase to albitic plagioclase \pm clays giving the grains a chalky white appearance (Sample 147-894G-12R-5, Pieces 7B, 7C, 7D). dote \pm calcite assemblages or occurs locally in zones of coarser grained gabbro and gabbronorite.

Lower temperature alteration of the primary mafic minerals associated with veining produced local new growth of actinolite, chlorite, smectitic clays, and iddingsite. Pervasive alteration of the primary pyroxenes is associated with the development of fibrous green actinolite around grain boundaries and fine-grained mixed-layered clays and smectite along exsolution lamellae. Fine-grained, fibrous clusters of actinolite often extend from the edges of pyroxene and olivine grains and coalesce to form irregular veinlets that crosscut neighboring plagioclase grains. The latest phase of alteration in the pyroxenes is characterized by patches of fine-grained, clay-rich, and smectitefilled microveins, giving the altered pyroxenes a dark green-black appearance.

\section{Brittle Deformation}

Brittle deformation, defined by cataclasis at the shallower depths (above $\approx 38 \mathrm{mbsf}$ ) and multiple phases of veining, is characteristic of the gabbros at Site 894. Virtually no evidence for intercrystalline plastic deformation is found, in marked contrast to the highly ductile style of deformation observed in Hole 734B gabbros from the slowspreading Southwest Indian Ridge (Cannat et al., 1991; Dick et al., 1991; Stakes et al., 1991). A pervasive mineral-filled fracture set is oriented west-northwest-east-southeast (after restoration with respect to stable magnetic vectors; Manning and MacLeod, this volume; MacLeod, Manning, et al., this volume) and contains chlorite/ prehnite or chlorite-smectite/zeolite assemblages (Fig. 3). This orientation suggests that the late veining was controlled by the rifting processes related to the propagation of the Cocos-Nazca Ridge and the ultimate formation of the Hess Deep Rift Valley (Shipboard Scientific Party, 1993a, 1993b; MacLeod et al., 1993; MacLeod, Manning, et al., this volume).

Veins

Macroscopic and microscopic veins are observed throughout the Site 894 gabbroic section. On the basis of mineralogy, type of wallrock alteration, and geometry, these veins can be summarized into three main types (see also Gillis, Mével, Allan, et al., 1993; Manning and MacLeod, this volume; Manning et al,, this volume): (1) $\mathrm{Ca}-\mathrm{Al}$ amphibole; (2) a composite of chlorite \pm prehnite \pm epidote \pm sphene \pm mixed-layered clay \pm carbonate; and (3) smectitic clay \pm chlorite \pm zeolite \pm calcite (Table 1).

Amphibole Veins. Discontinuous, Type 1 microscopic $(<30 \mu \mathrm{m})$ veins and rare macroscopic veinlets (up to $\approx 2 \mathrm{~mm}$ ), filled with green $\mathrm{Ca}-\mathrm{Al}$ amphibole (and rarely chlorite), define the earliest generation of fracturing leading to the infiltration of aqueous fluids and the pervasive static amphibolite facies alteration (Pl. 1, Fig. 2). This generation of veining includes a continuous spectrum of occurrences that ranges from discrete micron-sized amphibole grains at grain boundaries to a dense irregular network of amphibole-filled microveinlets along grain boundaries, crosscutting primary igneous grains, and locally completely replacing primary clinopyroxene grains. Electron microprobe analyses along individual amphibole microveins indicate a continuous range in compositions from magnesio-hornblende to actinolitic hornblende. The range in vein-amphibole compositions completely overlaps the range of amphibole compositions observed throughout the gabbroic section, but may show slightly higher Tschermaks substitutions than do the coexisting amphibole pseudomorphs of clinopyroxene in the same sample (Fig. 2).

Chlorite-bearing Macroscopic Veins. Two sets of distinct chloriterich macroscopic veins (Types 2 and 3), ranging in size from $0.1 \mathrm{~mm}$ to several $\mathrm{mm}$, postdate the early amphibole microvein generations and form the most dominant fracture fillings observed throughout the cored section at Site 894 (Fig. 3; see also Manning and Mac- 
Table 1. Results of XRD analyses of fine-grained phyllosilicates in veins and as alteration products in cataclastically deformed gabbros (Holes $894 \mathrm{~F}$ and 894G).

\begin{tabular}{|c|c|c|c|c|c|c|c|c|c|c|c|c|c|c|c|c|c|c|c|c|}
\hline $\begin{array}{l}\text { Core, section, } \\
\text { interval }(\mathrm{cm})\end{array}$ & Piece & $\begin{array}{l}\text { Depth } \\
\text { (mbsf) }\end{array}$ & Lithology & Deformation & $\begin{array}{l}\text { Vein } \\
\text { type }\end{array}$ & Halo & act & cpx & plg & pre & chl & $\mathrm{sm}$ & $\mathrm{sm} / \mathrm{il}$ & $\mathrm{chl} / \mathrm{sm}$ & cor & il & ep & zeo & $\mathrm{cc} / \mathrm{dol}$ & qtz \\
\hline \multicolumn{21}{|c|}{$\begin{array}{l}\text { Cataclasites/ultracataclasites } \\
147-894 \mathrm{~F} \text { - }\end{array}$} \\
\hline $1 \mathrm{R}-1,0-10$ & 1 & 0.00 & GB (bulk) & cat/ucat SZ & & & $\mathrm{XX}$ & & $\mathrm{XX}$ & $\mathrm{O}$ & & & & $\mathrm{X}$ & $\mathrm{XX}$ & & & & & \\
\hline IR-1, 0-2 & 1 & 0.00 & $\mathrm{~GB}(<2 \mu \mathrm{m})$ & ucat SZ & & & & & & & & & & & $\mathrm{XX}$ & & & & & \\
\hline IR-1, 20-25 & 4 & 0.20 & GB (vein) & cat, V & III & & & & & & & & & & & & & anl/wai & & \\
\hline $2 \mathrm{R}-1,27-36$ & 3 & 9.57 & GB (bulk) & cat, bx & & & $\mathrm{XX}$ & $\mathrm{X}$ & $\mathrm{XX}$ & & $X(s w)$ & & & & $X X$ & & & & & \\
\hline $2 \mathrm{R}-1,51-54$ & 7 & 9.81 & $\mathrm{~GB}(<2 \mu \mathrm{m})$ & ucat SZ & & & O & & & & & & & & $\mathrm{XX}$ & & & & & \\
\hline $2 \mathrm{R}-1.51-54$ & 7 & 9.81 & $\mathrm{~GB}(<2 \mu \mathrm{m})$ & cat & & & $\mathrm{O}$ & & O & & & & & & $\mathrm{XX}$ & & & & & \\
\hline $2 \mathrm{R}-1,57-58$ & 7 & 9.87 & GB (bulk) & cat $\mathrm{SZ}$ & & & $\mathrm{X}$ & & $\mathrm{XX}$ & $\mathrm{X}$ & $\mathrm{XX}(\mathrm{sw})$ & & & & & & & & & \\
\hline $2 R-1,58-59$ & 7 & 9.85 & GB (bulk) & ucat SZ & & & $\mathrm{XX}$ & & $\mathrm{XX}$ & $\mathrm{XX}$ & $\mathrm{X}$ & & & & & & & & & \\
\hline $3 \mathrm{R}-1,15-20$ & 4 & 16.95 & $\mathrm{~GB}(<2 \mu \mathrm{m})$ & cat, V & & & & & O & & $\mathrm{X}$ & & & & $\mathrm{XX}$ & & & & & \\
\hline $3 R-1,52-58$ & 9 & 17.32 & GB (bulk) & cat in SZ & & & $\mathrm{XX}$ & $\mathrm{XX}$ & $\mathrm{XX}$ & & $\mathrm{X}$ & & & & $x$ & & & & & \\
\hline $3 R-1,52-58$ & 9 & 17.32 & GB (bulk) & ucat SZ & & & & & $\mathrm{XX}$ & & $\mathrm{XX}(\mathrm{sw})$ & & & & $\mathrm{XX}$ & & & & & \\
\hline $3 R-1,52-58$ & 9 & 17.32 & $\mathrm{~GB}(<2 \mu \mathrm{m})$ & ucat SZ & & & $\mathrm{O}$ & & & & $\mathrm{O}(\mathrm{sw})$ & & & & $\mathrm{XX}$ & & & & & \\
\hline $3 R-1,81-83$ & 14 & 17.61 & $\mathrm{~GB}$ (vein) & cat, bx & III & & & & & & $\mathrm{XX}(\mathrm{sw})$ & & & $\mathrm{XX}$ & & $\mathrm{X}$ & & anl & $\mathrm{XX}$ & $\mathrm{XX}$ \\
\hline \multirow{2}{*}{\multicolumn{21}{|c|}{$\begin{array}{l}\text { Veins } \\
147-894 \mathrm{G} \text {. }\end{array}$}} \\
\hline & & & & & & & & & & & & & & & & & & & & \\
\hline $\begin{array}{l}2 R-3,51-53 \\
4 R-2,44-47\end{array}$ & $\begin{array}{l}6 \\
8\end{array}$ & $\begin{array}{l}32.06 \\
46.78\end{array}$ & $\begin{array}{l}\text { OL GB } \\
\mathrm{GN}(\mathrm{cg})\end{array}$ & v & II & $\begin{array}{l}N \\
D\end{array}$ & & & & O & $\begin{array}{l}0 \\
0\end{array}$ & $\begin{array}{l}X X \\
X X\end{array}$ & & $\mathrm{~T}$ & & & & & & \\
\hline $4 \mathrm{R}-2,52-54$ & $9 \mathrm{~A}$ & 46,86 & GN & V & III & M & & & & & $x x$ & $\mathrm{XX}(\mathrm{Ca})$ & & & & & & & dol & \\
\hline $6 \mathrm{R}-1,31-34$ & $4 C$ & 55.11 & $\mathrm{GN}$ & cat, V & III & M & & & & & $\mathrm{xx}$ & $\mathrm{XX}$ & & $\mathrm{T}$ & & & & & & \\
\hline $6 \mathrm{R}-1,13 \mathrm{I}-137$ & 12 & 56.11 & GN & V & II & M & & & & & & $\mathrm{XX}(\mathrm{Ca})$ & & & & & & & & \\
\hline $7 \mathrm{R}-2,37-39$ & 4 & 66.57 & GN & V & III & M & & & & & & & & $\mathrm{XX}$ & $\mathrm{XX}$ & & & & & \\
\hline $8 R-1,10-13$ & 2 & 68.60 & $\mathrm{GN}$ & V & III & $\mathrm{N}$ & & & & & $\mathrm{XX}$ & $\mathrm{XX}$ & & & & & & & & \\
\hline $8 \mathrm{R}-2,2-4$ & 1 & 70.02 & $\mathrm{GN}$ & DV & III & D & & & & & & $\mathrm{XX}(\mathrm{Ca})$ & & & & & & & $\mathrm{cc}$ & \\
\hline $9 \mathrm{R}-2,24-27$ & 1C & 75.89 & $\mathrm{GN}$ & V & III & $\mathrm{N}$ & & & & & $\mathrm{XX}$ & $\mathrm{x}$ & $\mathrm{T}$ & $\mathrm{X}$ & & & & & & \\
\hline $12 \mathrm{R}-3,24-26$ & IF & 96.97 & $\mathrm{GN}$ & $\mathrm{V}$ & II & M & & & $\mathrm{XX}$ & $\mathrm{XX}$ & $\mathrm{X}$ & $\mathrm{XX}$ & & & & & & & & \\
\hline $12 \mathrm{R}-3,24-26$ & IF & 96.97 & $\mathrm{GN}$ & V & III & $\mathrm{N}$ & & & & & & & & $\mathrm{XX}$ & $\mathrm{XX}$ & & & & & \\
\hline $12 \mathrm{R}-5,48-52$ & $7 \mathrm{~B}$ & 100.21 & GN & DV & II & D & $\mathrm{T}$ & & $\mathrm{XX}$ & $\mathrm{XX}$ & $\mathrm{XX}$ & & & $\mathrm{XX}$ & & & $\mathrm{XX}$ & & & \\
\hline $12 \mathrm{R}-5,56-57$ & $7 \mathrm{C}$ & 100.29 & $\mathrm{GN}$ & DV & II & D & $\mathrm{X}$ & & $\mathrm{XX}$ & & $\mathrm{X}$ & $\mathrm{XX}$ & & & & & & & & \\
\hline $13 R-3,37-41$ & 3 & 106.60 & $\mathrm{GN}$ & V & II & $\mathrm{N}$ & & & $\mathrm{T}$ & $\mathrm{O}$ & $\mathrm{XX}$ & & & & $\mathrm{XX}$ & & & & & \\
\hline $13 \mathrm{R}-3,60-61$ & 5 & 106.83 & GN & V & II & $\mathrm{N}$ & $\mathrm{X}$ & & $\mathrm{x}$ & & $\mathrm{XX}$ & & & $\mathrm{X}$ & & & & & & \\
\hline $13 \mathrm{R}-3,60-61$ & 5 & 106.83 & $\mathrm{GN}$ & V & III & $\mathrm{N}$ & & & & & $\mathrm{T}$ & $\mathrm{XX}$ & & & & & & & $\mathrm{cc}$ & \\
\hline
\end{tabular}

Notes: Mineral abbreviations are: act = actinolite; $\mathrm{cpx}=$ clinopyroxene; $\mathrm{plg}=$ plagioclase; pre = prehnite; $\mathrm{chl}=\mathrm{chlorite} ; \mathrm{sm}=\mathrm{smectite} ; \mathrm{sm} / \mathrm{il}=\mathrm{smectite} / \mathrm{illite}$ mixed-layered clay; chl $\mathrm{sm}=$ chlorite/smectite mixed-layered clay; $\mathrm{cor}=$ corrensite (regular mixed-layered chlorite/smectite clay); il = illite; $\mathrm{ep}=\mathrm{epidote;} \mathrm{zeo=zeolite}($ anl $=$ analcime; wai = wairakite): $\mathrm{cc}=$ calcite; dol $=$ dolomite, qtz $=$ quartz. Lithology abbreviations: $\mathrm{OL} \mathrm{GB}=$ olivine gabbro; $\mathrm{GB}=\mathrm{gabbro} ; \mathrm{GN}=$ gabbronorite; $(\mathrm{cg})=\mathrm{coarse}-$ grained. Vein types II and III as defined in text. Relative presence of alteration halos defined as negligible (N), minor (M), or distinct (D). Relative abundance of alteration phases in cataclastic samples and veinfillings as determined by XRD analysis are denoted as $\mathrm{T}=$ trace; $\mathrm{O}=$ weak reflections, $\mathrm{X}=$ major reflections are present, $\mathrm{XX}=$ strong reflections; $(\mathrm{sw})=$ major reflections for chlorite shift after glycolation indicating the presence of swelling chlorite; $(\mathrm{Ca})=\mathrm{Ca}$-rich smectite variety. Deformation characteristics of gabbroic rocks are defined as: cat $=$ cataclastic; ucat = ultracataclastic; $\mathrm{SZ}=$ shear zone; $\mathrm{bx}=$ brecciated, $\mathrm{V}=$ veined; $\mathrm{DV}=$ densely veined. All XRD results are from comparison of oriented air-dried and ethylene glycol solvated clay-size fractions of vein material as well as bulk or clay size fractions in cataclastically deformed samples.

Leod, this volume). Fractures filled by Type 2 veins are composed of chlorite with varying proportions of prehnite, clays, epidote, sphene, calcite (or dolomite), and secondary feldspar (albite and Kfeldspar). These veins are commonly zoned with light green chlorite lining vein margins, followed by a thin $(<10 \mu \mathrm{m})$ seam of brown chlorite/smectite mixed-layered clay, with discontinuous patches of blocky to pseudoboytriodal prehnite \pm epidote \pm sphene \pm carbonate in the centers. Thicker Type 2 veins are typically associated with abundant discontinuous microveins forming a branching network with strong wall-rock alteration to secondary albitic plagioclase, actinolite, chlorite, sphene, and less commonly secondary clinopyroxene, epidote or prehnite. Mineralogies of the microfracture-filling phases may vary depending on the mineralogies of the primary phase they are cutting. Secondary alteration, dominated by the breakdown of plagioclase to albitic plagioclase \pm prehnite \pm clays, is generally restricted to alteration halos a few $\mathrm{mm}$ to several $\mathrm{cm}$ thick. As the density of the veins increases, complex, diffuse anastomosing zones (>10 cm thick) with pervasive wall-rock alteration develop, with local zones of brecciated clasts of altered primary phases incorporated in a prehnite-dominated matrix (e.g., Sections 147-894G8R-1, 147-894G-11R-1, and 147-894G-12R-5; Figs. 4, 5A). Chlorite and vuggy prehnite veins also cut pervasively altered, sulfiderich cataclastic zones in Hole $894 \mathrm{~F}$ and the upper $30-40 \mathrm{~m}$ of Hole 894G (Fig. 5B).

Thin, sinuous, discontinuous Type 3 veins comprise the latest phase of fracture-fillings. They are filled with varying proportions of chlorite, mixed layered chlorite/smectite, smectite, calcite, and minor zeolite, and typically occur as irregular coatings on fractures and on the broken ends of core pieces. Wall-rock alteration is similar to that of the chlorite-prehnite Type 2 veins, but may not always be present. When present, alteration halos are commonly limited to a few millimeters. The chlorite-clay veins are locally zoned with light green, fibrous chlorite lining the walls and brownish-green smectitic clays \pm calcite \pm zeolite in the centers. Thicker veins are associated with irregular discontinuous chlorite \pm smectite-veinlets filling microfractures that crosscut or follow grain boundaries of the variably altered primary phases ( $\mathrm{Pl}$. 1, Fig. 4).

In some cases, Type 2 veins follow the geometries of the Type 3 veins and occur as late residual fillings in the centers of the earlier veins. The zoned nature of the Type 2 and 3 veins suggests multiple stages of fracturing and filling; that is, a fracture is opened and filled with one phase, then is reopened and sealed by another phase. The presence of undeformed chlorite rimming composite veins with brecciated components in a prehnite matrix in the centers indicates that fragments of primary phases were incorporated in and transported by the hydrothermal fluids, which suggests that processes of hydrothermal brecciation were locally important during the lower greenschist to zeolite facies alteration of the Site 894 gabbros (Fig. 5A). Discontinuous veins and lenses with zeolite fillings comprise the latest stage of Type 2 veining.

Shipboard XRD studies, performed on several bulk samples of chlorite-bearing Type 2 and 3 veins in Hole 894G (Gillis, Mével, Allan, et al., 1993), have been complemented by analyses of bulk fracture-fillings and clay-size fractions $(<2 \mu \mathrm{m})$ separated from a number of similar veins in order to better characterize the mineralogies and structures of the fine-grained phyllosilicate phases. Sample numbers 


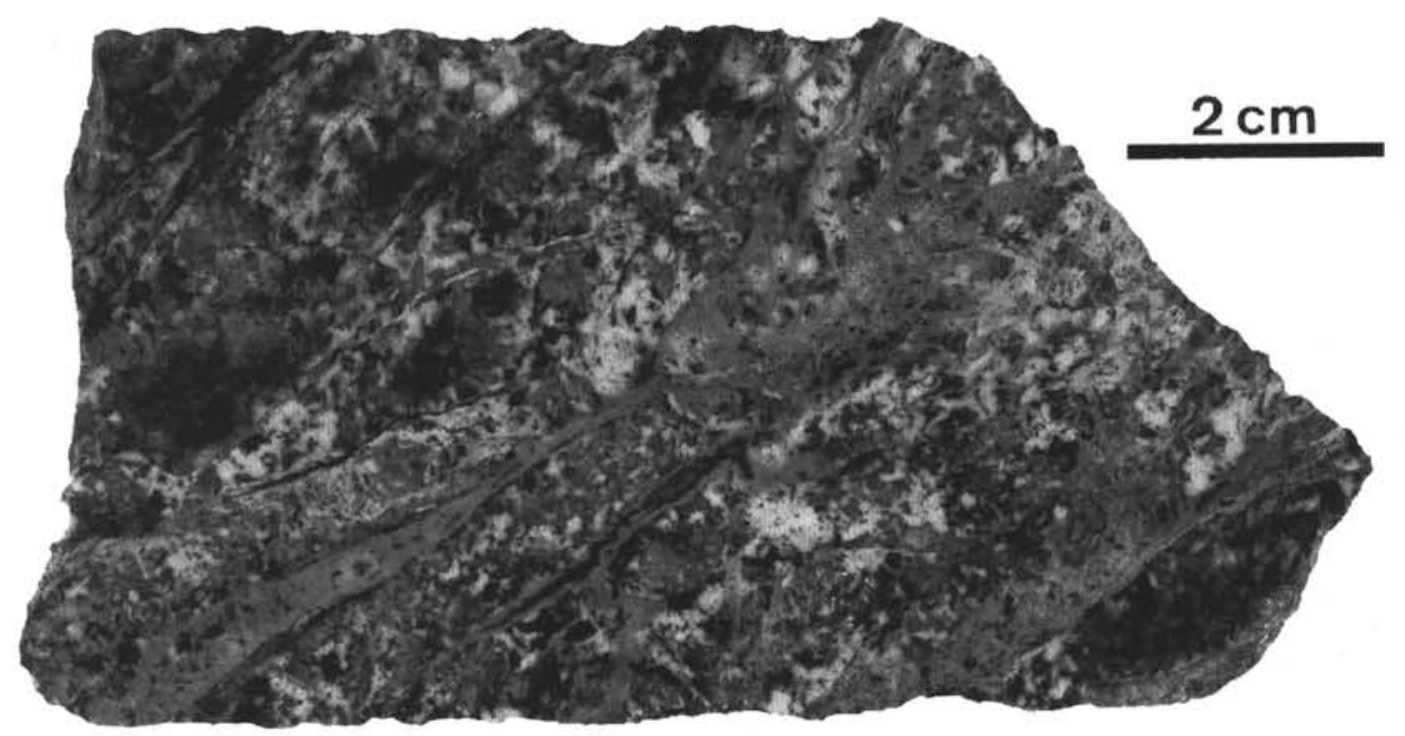

Figure 4. Hand sample photograph of extensive wall-rock alteration, brecciation, and development of subparallel cataclastic zones associated with dense chlorite/prehnite veining. Wall-rock mineralogies are altered to albitic plagioclase, actinolite, mixed-layered chlorite/smectite clays \pm chlorite (Sample 147-894G$8 \mathrm{R}-\mathrm{I}$, Piece II, 140-150 cm).
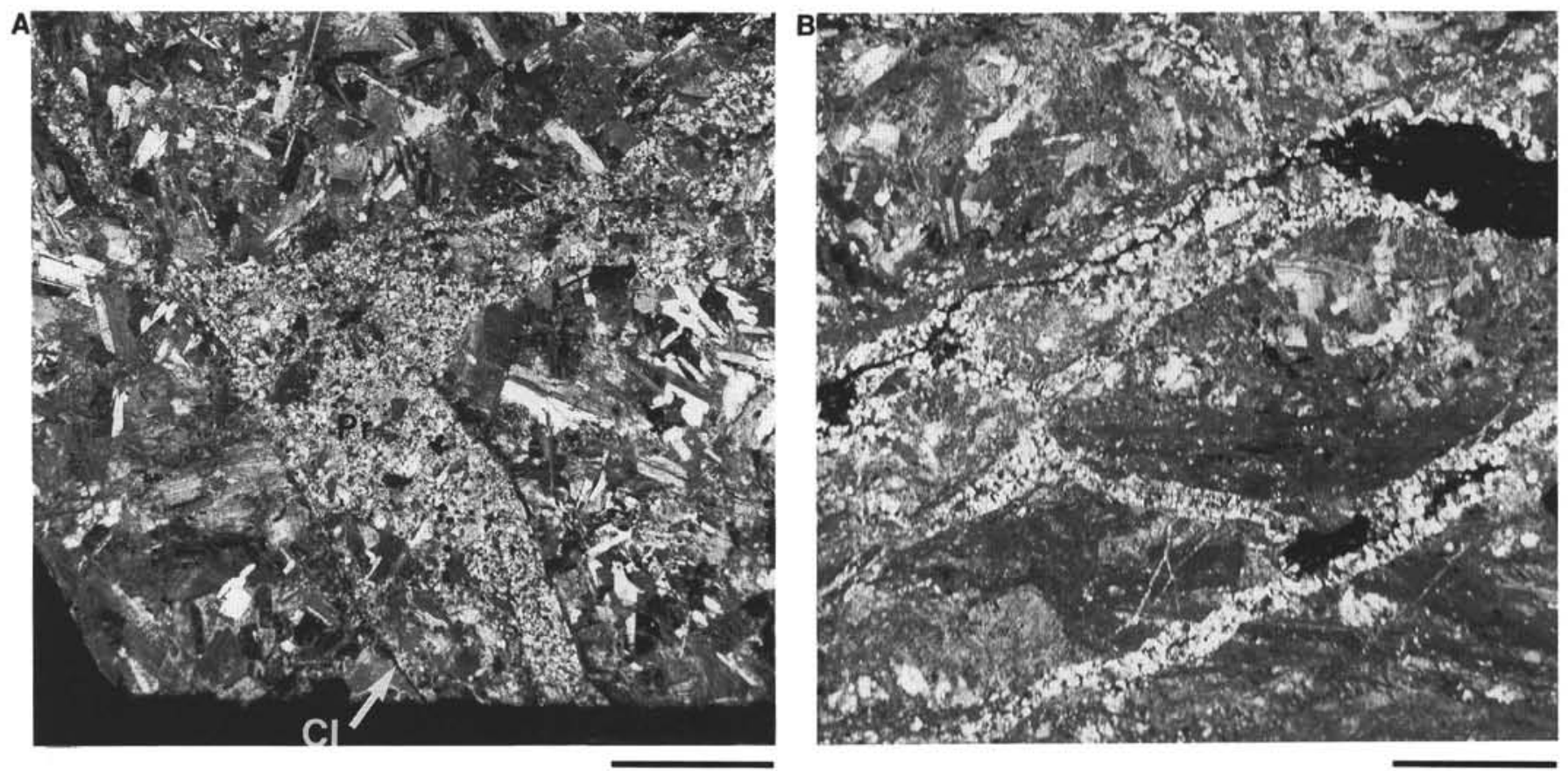

Figure 5. A. Full thin-section photomicrograph of incipient cataclasis and local brecciation associated with emplacement of chlorite/prehnite veins. A thin rim of undeformed chlorite $(\mathrm{Cl})$ lines the vein walls with brecciated clasts set in blocky prehnite (Pr) matrix in the centers of the veins (Sample 147-894G-2R-3, Piece 3,11-12 cm). B. Full thin-section photomicrograph of subparallel cataclastic layers cut by vuggy prehnite vein. Scale bars are $0.5 \mathrm{~cm}$.

and results are summarized in Table 1 . The results indicate a large spectrum of phyllosilicate assemblages in the fracture fillings. Chlorite occurs in both vein types and is easily identified by a series of regular basal reflections that are not influenced by ethylene glycol treatment. Wide peak shapes and slight shifts in d-spacings upon glycolation indicate the presence of poorly crystallized, slightly expandable chlorite in some samples. Mixed layered chlorite/smectite in regular or irregular layers occur together with chlorite in the Type 2 and 3 veins; whereas the Type 3 veins are typically more smectiterich. Irregular smectite/illite varieties are rare. The occurrence of smectite and smectite in irregular mixed layers is characterized by distinct shifts in the diffraction patterns and the occurrence of first and third order reflections at approximately $17 \AA$ and $5.64 \AA$, and the appearance of well-defined second order reflections at $8.46 \AA$. Carich varieties of smectite are indicated by broad peak distributions of the $(005)$ reflection between $27^{\circ}$ and $30^{\circ} 2 \theta$ in air dried samples. Both regular and randomly interstratified trioctahedral chlorite/smectite have been identified by shifts in reflections after glycolation and/ or heating to $375^{\circ} \mathrm{C}$. The presence of corrensite, a trioctahedral chlorite/smectite in regular layers, is indicated by $(001)$ reflections at 
about $29 \AA, 14.8 \AA .7 .3 \AA .4 .8 \AA$, and $3.5 \AA$. After glycolation, the first and third reflections shift to $31-32 \AA$ and $7.8 \AA$. The latter reflection, corresponding to the superstructure $004^{*}$, is characteristic for corrensite and appears at approximately $11.3^{\circ} 2 \theta$ upon glycolation (Moore and Reynolds, 1989). Reflections for prehnite, amphibole, calcite, dolomite, and plagioclase were also observed in analyses of bulk vein samples, and may in part reflect wall-rock mineralogies. Representative X-ray diffractograms showing the characteristic peak positions and d-spacings for air-dried and ethylene glycol-solvated Type 2 and 3 veins in the Hole $894 \mathrm{G}$ gabbroic section are shown in figures 25 and 26 (Site 894) in Gillis, Mével, Allan, et al. (1993).

The morphology and growth characteristics of one representative Type III vein (Sample 147-894G-4R-2, Piece 9A, 52-54 cm), which according to XRD contains a mixture of smectite and chlorite (Table * 1), was investigated under SEM equipped with qualitative analytical facilities. The SEM observations indicate that the clays form dense rigid sheets that were precipitated as successive, scaly layers from the wall of the fracture (Fig. 6A). The center of the vein is filled with dense smectitic clay sheets, forming homogeneous rosettes with straight edges (Fig. 6B), typical of fracture- and void-filling authigenic minerals (A.M. Karpoff, pers. comm., 1994). Qualitative chemical analyses indicate that the chlorite-smectite clays have relatively homogeneous, constant compositions and are rich in $\mathrm{Fe}$ and $\mathrm{Mg}$ and relatively poor in $\mathrm{Al}$.

\section{Cataclastic Deformation}

Although non-displacive microfracturing and veining are by far the most dominant effect of brittle deformation processes at Site 894, distinct zones of cataclastic deformation and shearing were recovered at shallow levels ( $\approx$ upper $40 \mathrm{~m}$ of section). At depths below approximately 38 mbsf in Hole $894 \mathrm{G}$, brecciation and cataclasis is rare and is limited to intervals of dense chlorite-prehnite veins with pervasive alteration of plagioclase (e.g., Sections 147-894G-8R-1, 147-894G11R-1, and 147-894G-12R-5; see Figs. 3, 4). This suggests locally high pore fluid pressures during hydrothermal alteration. In Hole $894 \mathrm{~F}$ and at shallow levels in Hole $894 \mathrm{G}$, faulting is associated with a continuum of cataclastic development, ranging from protocataclasites through cataclasites to ultracataclasites in narrow shear zones (Gillis, Mével, Allan, et al., 1993). In hand sample, the cataclastic zones have porphyroclastic textures or appear brecciated, and are associated with pervasive alteration dominated by the alteration of plagioclase and the formation of phyllosilicates which locally define a foliation (Fig. 7). Very thin ultracataclastic shear bands commonly cut discontinuously through the cataclastic zones. The foliation, which is associated with alteration in the cataclastic zones, appears to rotate from a high angle into parallelism with these fine cross-cutting shear bands (Fig. 7; see also fig. 30 in Gillis, Mével, Allan, et al., 1993; Site 894). The macroscopic texture is suggestive of Riedel shear geometries (Fig. 7; see also fig. 32 in Gillis, Mével, Allan, et al., 1993; Site 894). The cataclastic shear zones are cut at high angles by vuggy chlorite-prehnite veins or less commonly by zeolite veins (Fig. 5B).

Microscopically, the cataclastically deformed zones exhibit very heterogeneous grain-sizes and degree of alteration and reflect the variable extent of cataclasis over a cm-scale. The cataclastic fabrics are characterized by grain-size reduction by microcracking of the primary igneous phases, producing subrounded to angular porphyroclasts of variably altered plagioclase, pyroxene, amphibole, and/or compound gabbroic clasts, set in a fine-grained clast-clay matrix (Pl. 1, Figs. 5 and 6). With increasing strain, the average grain size of the porphyroclasts and the groundmass becomes progressively smaller and the proportion of phyllosilicates increases. Occasionally cataclasis progresses to the extent that ultracataclastic shear zones or bands develop (Pl. 1, Fig. 6). Progressive cataclastic deformation associated with extensive veining and sulfide-rich hydrothermal alteration is particularly well developed in Section 147-894G-2R-3. Detailed mi-
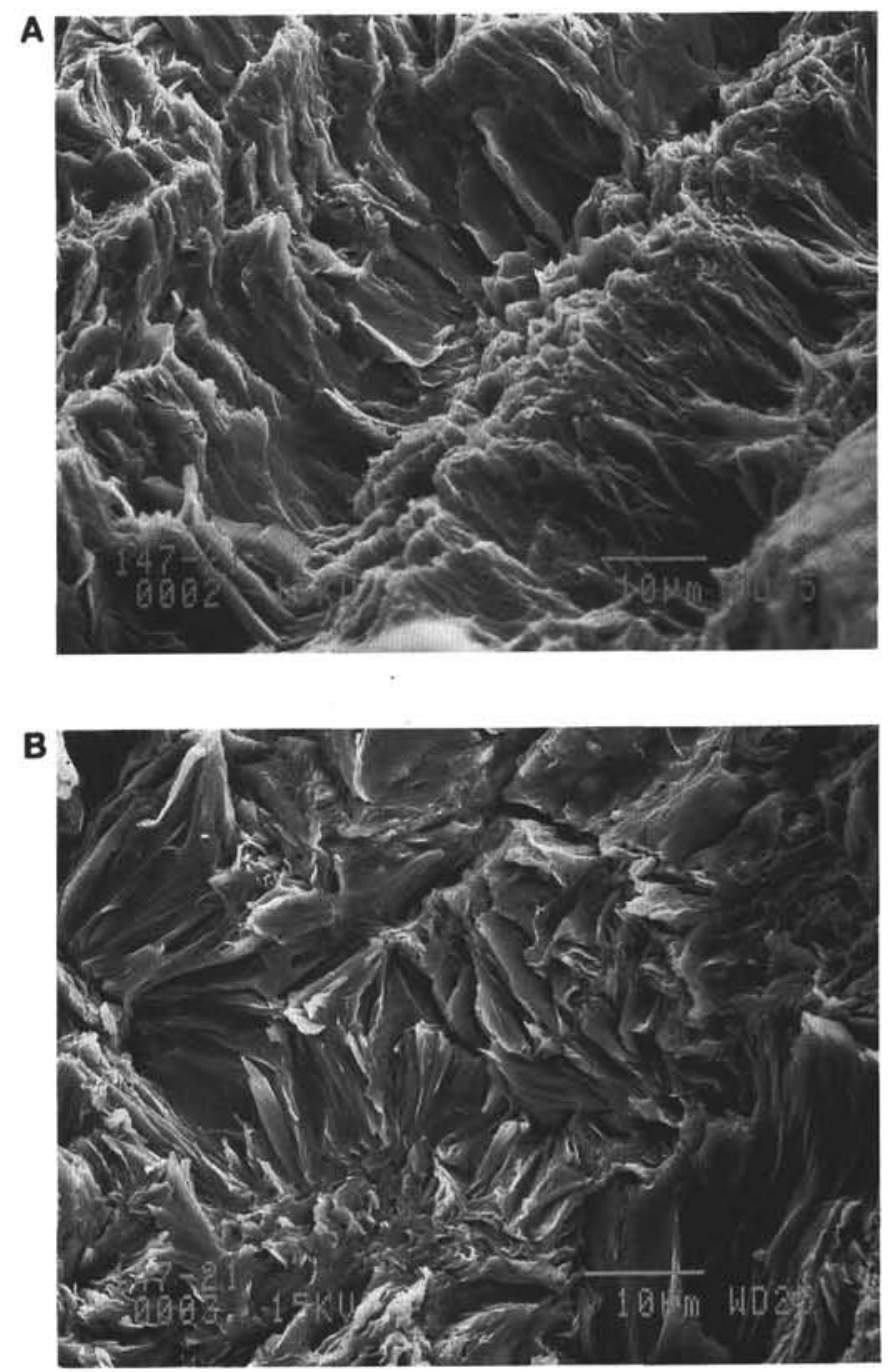

Figure 6. SEM images of vein-filling Fe-Mg smectite/chlorite clays in Sample 147-894G-4R-2, Piece 9A, 52-54 cm. A. Relatively dense rigid layers of clays with slightly wavy grain boundaries have been precipitated along the wall of the fracture (lower right side of photograph) and successively pile up to form a fish-scale texture. B. The center of the vein is filled with dense smectitic clay layers organized in a rosette texture, typical of authigenic mineral growth in open fissures and pore spaces.

croscopic descriptions of this section and the cataclastic zones in Hole 894F are given in Gillis, Mével, Allan, et al. (1993, pages 76 and 81-83).

Shipboard X-ray diffraction determinations were carried out on bulk samples from the characteristic fine-grained deformation zones in Hole $894 \mathrm{~F}$ and were repeated on clay-size fractions $(<2 \mu \mathrm{m})$ from representative samples in this study (Table 1). The results of the XRD analyses on the bulk samples in the cataclastic intervals show characteristic reflections for chlorite, tremolitic amphibole, sodic plagioclase, diopsidic pyroxene, prehnite, regular mixed-layered chlorite/ smectite, and rarely irregular, mixed-layered chlorite/smectite (Table 1). Smectite is entirely missing, which distinguishes the phyllosilicate assemblages in the cataclasites from those in the Type 2 and 3 veins. The predominance of swelling varieties of chlorite is indicated by relatively wide peaks at $14.2 \AA$ and $7.1 \AA$, which expand to an average d-spacing of $14.7 \AA$ and $7.9 \AA$ after glycolation. The presence of the regular mixed-layered chlorite-smectite mineral, corrensite, is indicated by first, second, and fourth order reflections at $27.5-28.9 \AA$, 


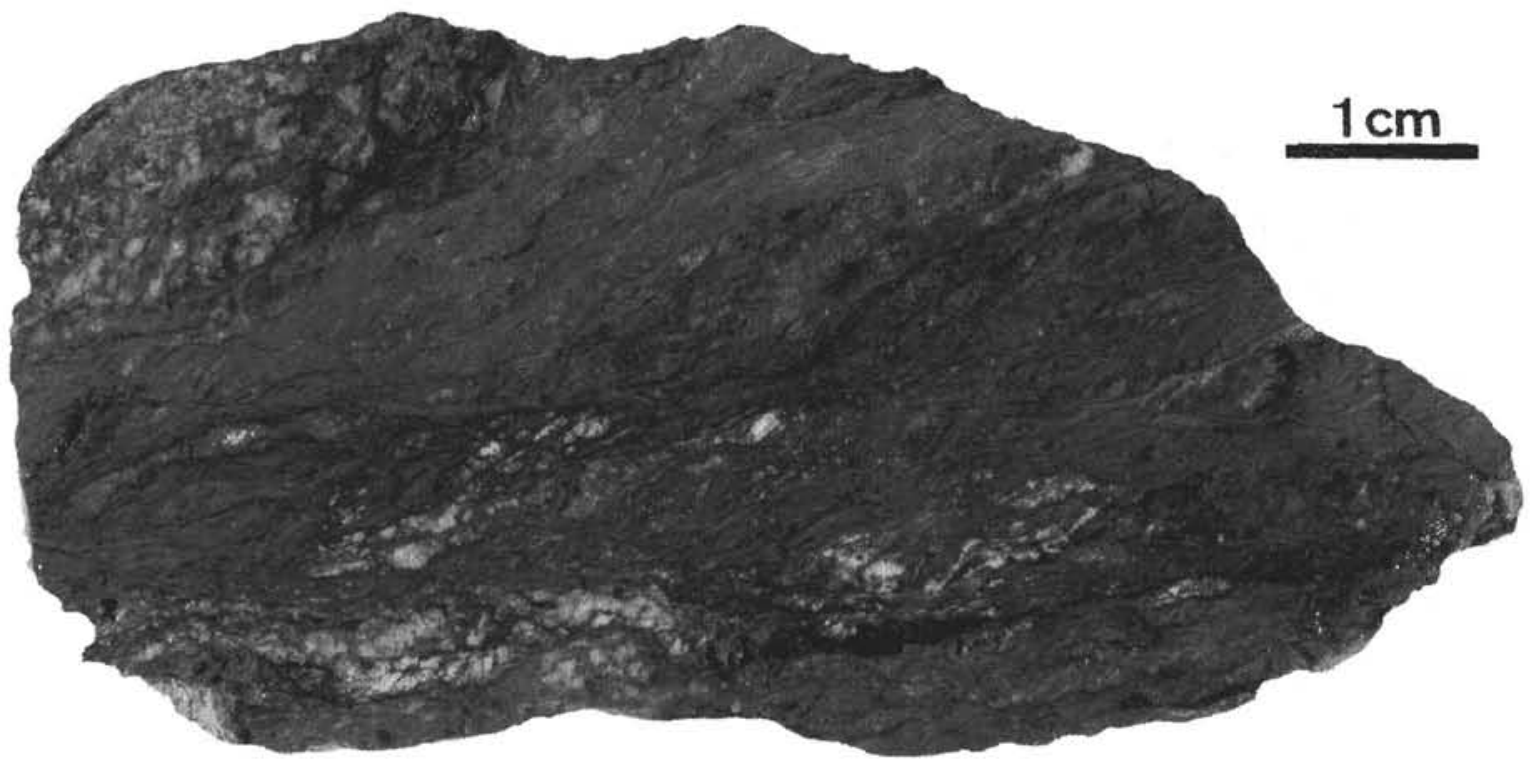

Figure 7. Hand sample photograph of foliated gabbro with variable grain sizes and porphyroclastic textures. Foliation, defined by clay-sized phyllosilicates and fine-grained clasts, rotates from a high angle into parallelism with shear bands (Sample 147-894F-1R-1, Piece 1, 0-10 cm).

13.3-14.5 $\AA$, and approximately $7.2 \AA$. After glycolation the first two reflections shift to $30.7-32.0 \AA, 15.3-15.8 \AA$, respectively, with the characteristic $\mathrm{d}(004)$ reflection appearing at $7.8 \AA$ (Moore and Reynolds, 1989). Detailed XRD analyses of clay-sized fractions $(<2 \mu \mathrm{m})$ from the ultracataclasites and cataclasites indicate that chlorite and corrensite are the predominant phyllosilicates (Table 1) in the finegrained matrix. XRD determinations on two samples of Type 3 zeolite veins crosscutting the cataclastic zones indicate analcime and wairakite. Representative X-ray diffractograms showing the characteristic peak positions and d-spacings for air-dried and ethylene glycol-solvated from the bulk matrix material in the cataclasites and ultracataclasites from Hole 894F are shown in figure 33 (page 83) in Gillis, Mével, Allan, et al. (1993).

Samples from two cataclastic zones have been further analyzed in TEM (Samples 147-894F-3R-1, Piece 4, 15-20 cm and 147-894F$3 \mathrm{R}-1$, Piece 9, 51-56 cm). The two samples appear to be very similar and therefore observations are presented together. At relatively low magnification (15-30 kX) the overall fabric and interrelationship of varying minerals is easily observed (Figs. 8,9 ). The ground mass appears largely altered with fine subrounded remnant clastics surrounded by wavy alteration products, which are predominantly phyllosilicates and fibrous amphibole (Fig. 8). Evidence for brittle deformation is common in the larger clasts (Fig. 9). Grain-scale (through-going) cracks, as well as subparallel sets of fine microcracks contained within single grains, moiré fringes (which can result from the misorientation of superimposed grain fragments), and angular grains are all common. Cracks of all scales contain alteration products. This suggests that cracks may serve as nucleation sites for chemical alteration. Fine microcracks within grains can cause patchy undulatory extinction at the optical scale (e.g., Tullis and Yund, 1977). This is the likely cause of the undulatory extinction observed in a number of samples (Gillis, Mével, Allan, et al., 1993). No microstructural evidence for intracrystalline plasticity such as dislocation recovery structures or recrystallized (strain induced) grains has been observed in either specimen.

Samples were also observed using high resolution (100 to 200 $\mathrm{kX}$ ) imaging techniques where lattice fringe images with periodicities related to the crystal structure can be resolved (Fig. 10). Again, at this scale both samples exhibit similar mineralogy and microfabrics. Overall, crystal packets are subparallel and take on a more ran- dom orientation only in the vicinity of microcracks in the clasts. Low angle boundaries form between crystal packets where the lattice planes are not perfectly parallel. Small micropores (as large as $\approx 100$ $\mathrm{nm}$ ) are found in the vicinity of such areas, as well as in regions where crystal packets part slightly. Quantification of micropores is difficult in TEM because sample preparation by ion thinning can enlarge or also create pores. Nevertheless, location and shapes of pores can be useful for inferring potential fluid pathways. Chlorite is commonly observed as discrete crystal packets approximately 15-30 nm in thickness (Fig. 10). Corrensite layers with $24 \mathrm{~nm}$ ( 24 A) lattice fringe periodocities are also found, but are not as ubiquitous as chlorite. Within the corrensite crystal packets, errors in the structural layering can be found generally in the form of an extra chlorite layer or a smectite layer termination creating a partial edge dislocation. A few dislocations and kinks are also observed, however the defect density is in not high. The basic mineralogy observed in TEM corroborates the XRD results.

\section{STABLE ISOTOPE CONSTRAINTS ON HYDROTHERMAL ALTERATION}

Gabbroic rocks that have not interacted with external fluids should have bulk rock oxygen isotope ratios within the range known for fresh mid-ocean ridge basalts $(=5.8 \pm 0.3 \%$; ; see review by Muehlenbachs, 1986). Small variations in whole-rock oxygen isotope ratios may result from variations in modal mineralogies, in particular, in the modal percentages of plagioclase and oxides, which tend to be the most ${ }^{18} \mathrm{O}$ enriched and ${ }^{18} \mathrm{O}$-depleted phases, respectively, in mafic rocks. However, these variations are minimal, and unaltered magmatic plagioclase tends to lie in a close range from $6.3 \pm 0.1 \%$ (Dunn, 1986). Deviations away from these reference values can be produced by seawater-rock interactions, whereby the final composition of the rock will reflect the temperatures of alteration as well as fluid/rock ratios (Taylor, 1977; 1984; Ito and Clayton, 1983). A number of stable isotope studies have shown that submarine weathering and hydrothermal alteration of the upper oceanic crust at temperatures below approximately $225^{\circ} \mathrm{C}$ result in a general enrichment in ${ }^{18} \mathrm{O}$, reflecting the greater proportions of newly formed smectite/chlorite clays and larger isotopic fractionations. Above these temperatures seawater-rock in- 
teractions produce depletions in ${ }^{18} \mathrm{O}$ in the lower crust, due to high temperature re-equilibrium and the formation of hydrous alteration products that tend to be more depleted in ${ }^{18} \mathrm{O}$ relative to the primary phases (e.g., Gregory and Taylor, 1981; Cocker et al., 1982; Alt et al., 1986b; Muehlenbachs, 1986). This general balance between processes of submarine weathering and low temperature metamorphism, producing ${ }^{18} \mathrm{O}$-enriched volcanic sequences and higher temperature, seawater hydrothermal alteration, producing ${ }^{18} \mathrm{O}$ depletions in lower crustal sequences, has been invoked as a critical mechanism contributing to the overall buffering of the oxygen isotope composition in the worlds oceans (Muehlenbachs and Clayton, 1976; Gregory and Taylor, 1981; Muehlenbachs, 1986). However, as new data becomes available this general model of the controls on the ${ }^{18} \mathrm{O}$ budget of the oceans has been questioned (Agrinier et al., 1988; Kempton et al., 1991; Lécuyer and Fourcade, 1991; Stakes et al., 1991; Stakes and Taylor, 1992). A balance between ${ }^{18} \mathrm{O}$-enrichment and ${ }^{18} \mathrm{O}$-depletion in the oceanic crust is not observed in all ophiolites, and in particular, may not be characteristic of hydrothermal alteration in slow-spreading environments (Agrinier et al., 1988; Lécuyer and Fourcade, 1991).

The oxygen, hydrogen, and carbon isotope results of fresh and altered phases as well as vein minerals from variably altered and deformed gabbros in Holes $894 \mathrm{~F}$ and $895 \mathrm{G}$ are given in Table 2 and are shown graphically in Figures 11 through 13. As it was impossible to separate the various generations of $\mathrm{Ca}-\mathrm{Al}$ amphibole ranging in composition from actinolite to magnesio-hornblende, their isotopic compositions are considered to reflect an integration of the amphibolite to greenschist facies phase of hydrothermal alteration affecting the Site 894 gabbros. These stable isotope data of the Hess Deep lower crust, combined with petrology and phase chemistry, provide new constraints from a fast-spreading environment on the general model of hydrothermal alteration and oxygen isotope exchange in the oceanic crust. These data further allow an assessment of the degree to which seawater penetrates and reacts with the lower oceanic crust and provides constraints on the role of magmatic fluids in deep-seated hydrothermal systems. This study compliments the work of Lécuyer and Gruau (this volume), who document the oxygen and strontium isotope exchange during the early high-temperature evolution of the Site 894 gabbros.

\section{Oxygen Isotope Ratios}

A compiled profile of the oxygen isotope ratios of plagioclase, $\mathrm{Ca}-\mathrm{Al}$ amphibole, and clay mineral separates as well as vein-fillings from the gabbroic section in Holes $894 \mathrm{~F}$ and $894 \mathrm{G}$ is shown as a function of depth and lithology in Figure 11. The range of whole rock $\delta^{18} \mathrm{O}$ values of plutonic rocks cored at Site 894 (Lécuyer et al., 1993; Lécuyer and Gruau, this volume) and recovered during previous submersible surveys (Agrinier et al., in press) are shown as a shaded band from approximately $3 \%$ to $6 \%$. The upper limit of this range corresponds to oxygen isotope ratios of unaltered oceanic volcanic and plutonic rocks $(\approx 5.8 \% \pm \pm 0.3)$. The mineral separates and veinfillings at Site 894 show a large range in $\delta^{18} \mathrm{O}$ values, with no clear distinction between lithology or depth. Two distinct groups relative to the mantle reference value can be recognized: (1) an ${ }^{18} \mathrm{O}$-depleted group defined primarily by low $\delta^{18} \mathrm{O}$ values of $\mathrm{Ca}-\mathrm{Al}$ amphibole and corrensite in the cataclasites; and (2) an ${ }^{18} \mathrm{O}$-enriched group with $\delta^{18} \mathrm{O}$ values greater than $7 \%$. The oxygen isotope ratios of both plagioclase and the clay vein-fillings are divided between these two groups (Fig. 11). The amphiboles, which reflect the alteration of primary clinopyroxene, show the least variations in compositions and lie in a general range of $3.5 \%,-5.5 \%$, with one sample showing a value of $2.2 \%$. The values of $<5 \%$ for amphibole are lower than those reported for relict pyroxene in the previous studies, and reflect a higher degree of fluid-rock interaction at moderate to high temperatures.

A depletion in ${ }^{18} \mathrm{O}$ relative to unaltered oceanic crust is characteristic of the Hess Deep gabbros and peridotites and clearly reflects hydrothermal alteration by fluids with a dominant seawater component

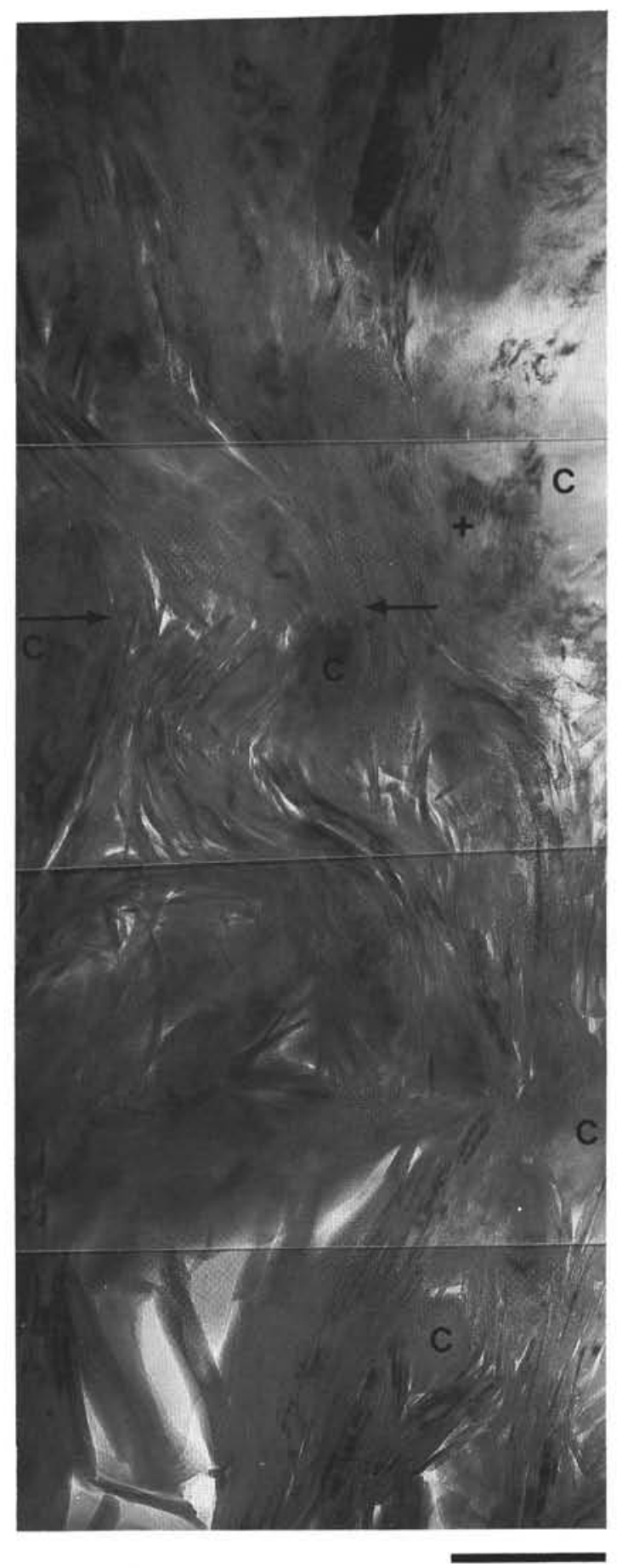

Figure 8. TEM photo mosaic of Sample 147-894F-3R-1, Piece 1, 45-50 cm, showing foliation fabric composed of phyllosilicates and fibrous amphibole appears undulating and feathery. A weak kink (or crenulation) is bracketed by arrows. Clasts (c) are rounded and commonly isolated within the fibrous matrix. Note moiré fringes ( + ) and abundance of micropores (white spaces) between the crystal packets of the foliation minerals. Thinning during sample preparation likely caused the big holes in lower left. Scale bar is $0.5 \mu \mathrm{m}$.

at temperatures greater than $350^{\circ}-400^{\circ} \mathrm{C}$ (see also Lécuyer et al., this volume; Früh-Green et al., this volume; Agrinier et al., in press). Since plagioclase and clay minerals are more sensitive to isotopic exchange than coexisting olivine, pyroxene, or amphibole, the variations in $\delta^{18} \mathrm{O}$ observed in plagioclase and the clays may record multi- 


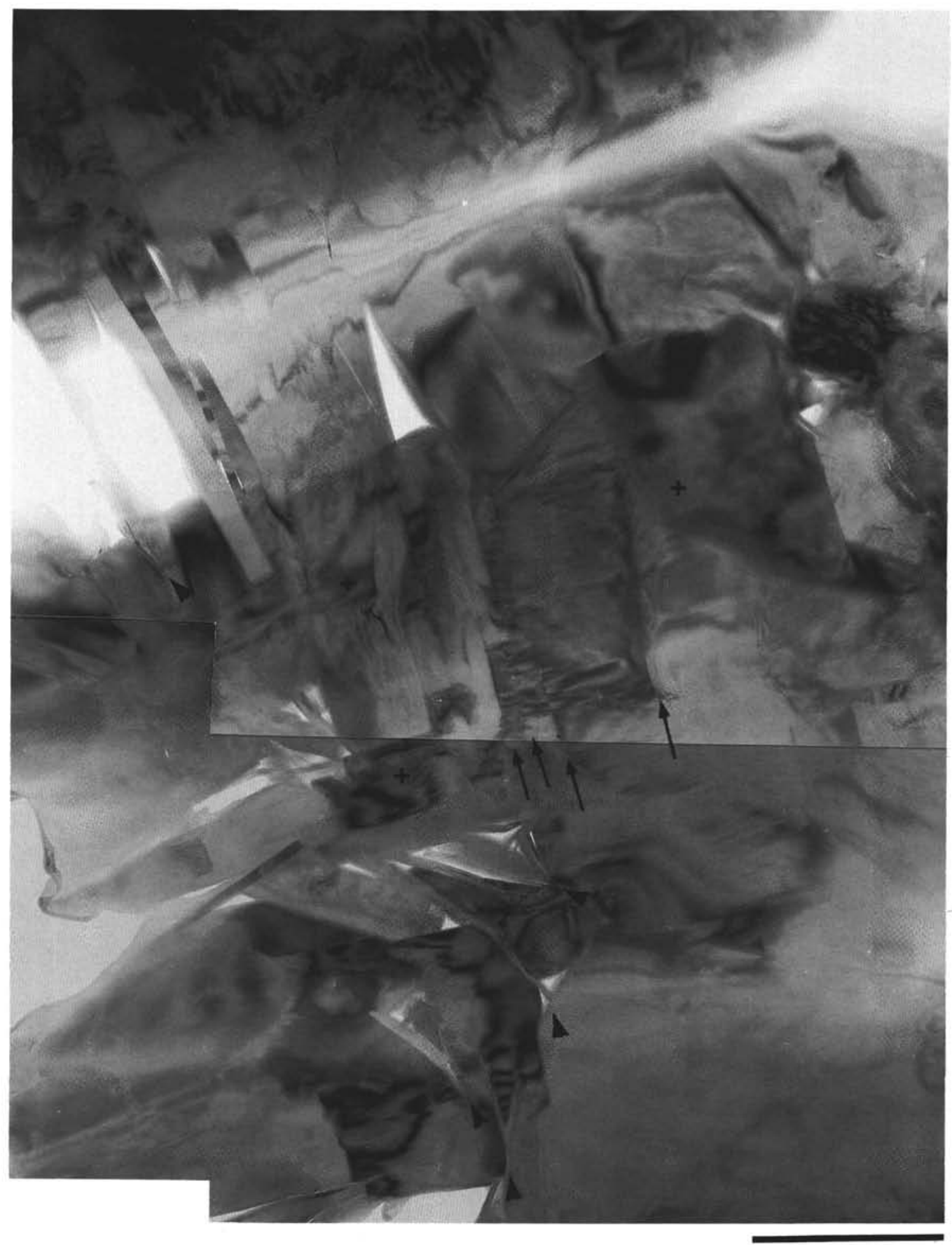

Figure 9. TEM photo mosaic of Sample 147-894F-3R-1, Piece 1, 45-50 cm, showing microcracks in clinopyroxene. Alteration products reside at grain boundaries and along microcracks (arrowheads). Fine subparallel alteration-free microcracks and moiré fringes ( + ) are contained within crystals. Scale bar is $1.0 \mu \mathrm{m}$.

ple phases of hydrothermal alteration over a large range of temperatures and varying fluid/rock ratios. The more negative $\delta^{18} \mathrm{O}_{\text {plg }}$ values are consistent with the low $\delta^{18} \mathrm{O}$ values in the amphibole and reflect exchange with seawater at high temperatures in a rock-dominated system. This suggests that seawater must have penetrated several kilometers into the lower crust during the earliest phase of amphibolite facies alteration.
The more positive $\delta^{18} \mathrm{O}$ values of plagioclase are up to $4 \%$ o higher than primary magmatic plagioclase $(6.3 \pm 0.1 \%$, Dunn, 1986). We interpret this enrichment in ${ }^{18} \mathrm{O}$ to be a combined result of progressive retrograde exchange at lower temperatures $\left(<300^{\circ}\right)$, possibly with more evolved ${ }^{18} \mathrm{O}$-rich fluids, and higher fluid/rock ratios. An enrichment in ${ }^{18} \mathrm{O}$ in the fluid is consistent with the global model of oxygen isotope buffering (e.g., Muehlenbachs and Clayton, 1976; Muehlen- 


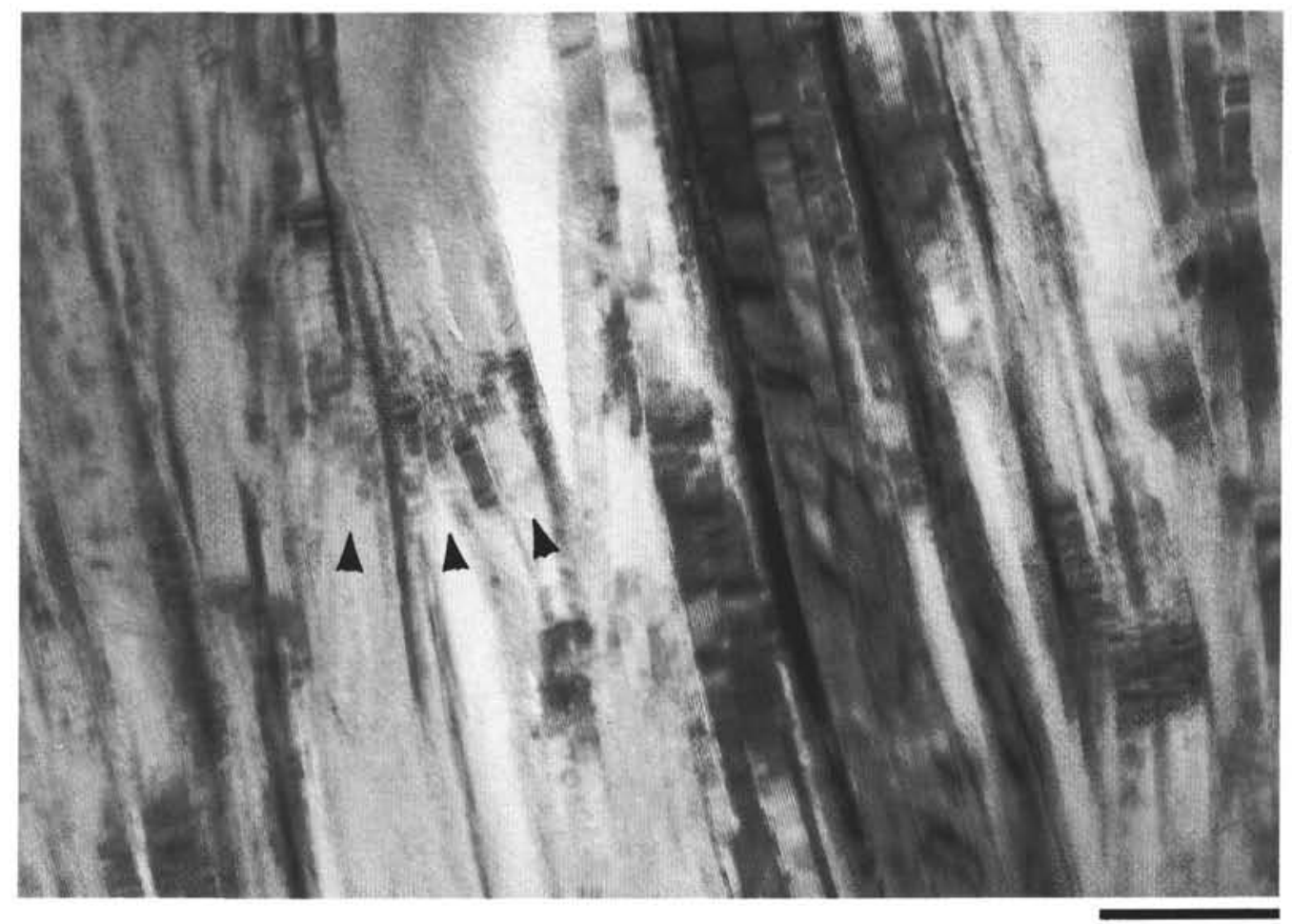

Figure 10. An example of a high-resolution image from Sample 147-894F-3R-1, Piece 9, 51-56 cm. Crystal packets are on the order of 10-30 nm wide. Most contain a lattice fringe spacing of $1.4 \mathrm{~nm}$, indicative of chlorite. Corrensite is observed near the arrowheads. The lattice spacing is $\sim 2.4 \mathrm{~nm}$, which is an intercalation of $1.4 \mathrm{~nm}$ (chlorite) and $1.0 \mathrm{~nm}$ (smectite) layers. Note low-angle crystal misorientation $\left(<10^{\circ}\right)$ between some crystal packets. Scale bar is $50 \mathrm{~nm}$.

bachs, 1986), in which depletions in ${ }^{18} \mathrm{O}$ during high-temperature alteration of lower level plutonic rocks result in ${ }^{18} \mathrm{O}$-enrichments in the hydrothermal fluids. Varying degrees of overprinting are also reflected in the variations in the bulk rock $\delta^{18} \mathrm{O}$ values of the gabbros from Hole $894 \mathrm{G}$, which are largely a function of the modal abundance and isotopic composition of plagioclase (Lécuyer et al., 1993; Lécuyer et al., this volume). The overall enrichment in ${ }^{18} \mathrm{O}$ in the Site 894 plagioclase can be correlated with a higher degree of lower greenschist to zeolite facies overprinting and albitization associated with brittle deformation in the gabbroic section and the formation of the discrete vein sets. Variations in fluid-rock ratios away from the veins is indicated by an approximate $0.5 \%$ difference between plagioclase analyzed from the alteration halos around veins and plagioclase from the unveined portion of the rock (Table 2). Enrichments in ${ }^{18} \mathrm{O}$ are also observed in samples in which, microscopically, the plagioclase appear relatively fresh. Similar, but less pronounced, retrograde overprinting of oxygen isotope ratios in plagioclase $\delta^{18} \mathrm{O}$ values is observed in the Site 895 gabbroic rocks (Früh-Green et al., this volume) and is largely related to the density of microfractures and discrete veins.

Not all of the cataclastically deformed samples show the same degree of ${ }^{18} \mathrm{O}$ enrichment. For example, in one heterogeneously deformed sample (147-894G-2R-3, Piece 3, 51-53 cm), plagioclase from the protocataclastic part of the sample has a $\delta^{18} \mathrm{O}$ value of $9.1 \%$; whereas the value of plagioclase from clasts in cataclastic shear zones in the sample is $4.9 \%$ (Table 2). The opposite relationship between cataclasites and ultracataclasitic shear zones is observed in the clay-sized fractions of Sample 147-894F-2R-1 (Piece $1,51-54 \mathrm{~cm}$ ). Corrensite is the dominant $<2 \mu \mathrm{m}$ phase in both parts of the sample, but is approximately $4 \%$ more enriched in ${ }^{18} \mathrm{O}$ in the ultracataclastic shear zone than in the cataclastic part of the sample. The value of $2.5 \%$ for corrensite in the cataclastic part of the shear is relatively low compared with clays in altered basalts (e.g., Stakes and O'Neil, 1982; Alt et al., 1986b). Similar low values have also been found in a number of mixed-layered chlorite/smectite vein-fillings (Table 2). These low values are comparable to oxygen isotope ratios of authigenic chlorite, swelling chlorite, and corrensite from sediments at the hydrothermal vent area recovered in Hole $858 \mathrm{~B}$ in the Middle Valley segment of the northern Juan de Fuca Ridge (Früh-Green et al., 1994; Früh-Green, unpubl. data). At Middle Valley, mineralogic and stable isotope studies show that chlorite and corrensite precipitated directly from circulating fluids at temperatures greater than $230^{\circ} \mathrm{C}$, and that corrensite may represent a metastable phase at these temperatures (Buatier et al., 1994). The low $\delta^{18} \mathrm{O}$ values of the corrensites and mixed-layered clays at Hess Deep may also reflect similar temperature conditions. The isotopic variations in the cataclastically deformed gabbros as well as large variations in the oxygen isotope ratios of the smectite- and chlorite/smectite-filled veins suggests that penetration of the hydrothermal fluids was primarily controlled by microfracture permeability and indicates channelled fluid flow with varying fluid/rock ratios and temperatures below approximately $250^{\circ}$. Calculations of oxygen isotope fractionation for the one calcite sample yield temperatures of approximately $110^{\circ}-140^{\circ} \mathrm{C}$ (based on experimental fractionation curves for calcite-water of O'Neil et al., 1969, and assuming a seawater $\delta^{18} \mathrm{O}$ value of $0-2 \%$ ).

Clear isotopic disequilibrium is evident by the large variations in $\Delta_{\text {plg-amp }}$ (defined as $\delta^{18} \mathrm{O}_{\mathrm{plg}}-\delta^{18} \mathrm{O}_{\text {amphibole }}$ ), and largely reflects the varying degree of isotopic re-equilibration of plagioclase. The isotopic compositions for plagioclase coexisting with amphibole in the Site 894 gabbros are shown in Figure 12. Plagioclase $\left(A n_{60}\right)$-amphibole fractionations at near igneous temperatures are approximately $1 \%$; whereas fractionations of approximately $2 \% \sigma_{-}-3 \%$ are predicted for equilibrium isotopic exchange at temperatures of $400^{\circ}-600^{\circ} \mathrm{C}$ (Bottinga and Javoy, 1973). Thus, under closed system conditions, isotopic compositions of plagioclase-amphibole pairs for the Site 894 samples would be expected to fall between the igneous equilibrium 
Table 2. Oxygen and hydrogen isotope ratios of mineral separates and vein-fillings from Holes 894F and 894G.

\begin{tabular}{|c|c|c|c|c|c|c|c|c|c|c|c|c|c|c|c|c|}
\hline $\begin{array}{l}\text { Core, section, } \\
\text { interval (cm) }\end{array}$ & Piece & $\begin{array}{l}\text { Depth } \\
\text { (mbsf) }\end{array}$ & Lithology & $\begin{array}{l}\text { Grain } \\
\text { size }\end{array}$ & Deformation characteristics & Alteration & $\begin{array}{c}\delta^{18} \mathrm{O} \\
\mathrm{plg}\end{array}$ & $\begin{array}{l}\delta \mathrm{D} \\
\text { pre }\end{array}$ & $\begin{array}{l}\delta^{18} \mathrm{O} \\
\text { amp }\end{array}$ & $\begin{array}{c}\delta \mathrm{D} \\
\mathrm{amp}\end{array}$ & $\begin{array}{l}\delta^{18} \mathrm{O} \\
\text { vein }\end{array}$ & $\begin{array}{c}\delta \mathrm{D} \\
\text { vein }\end{array}$ & $\begin{array}{l}\delta^{18} \mathrm{O} \\
\text { cor }\end{array}$ & $\begin{array}{l}\delta \mathrm{D} \\
\text { cor }\end{array}$ & $\begin{array}{l}\delta^{13} \mathrm{C} \\
\mathrm{cc}\end{array}$ & $\begin{array}{l}8^{18} \mathrm{O} \\
\mathrm{cc}\end{array}$ \\
\hline \multicolumn{17}{|l|}{$147-894 \mathrm{~F}-$} \\
\hline IR-1, $0-2$ & 1 & 0 & GB & VF & cat; ucat SZ & P & & & & & & & 5.5 & -50 & & \\
\hline $1 \mathrm{R}-1,25-31$ & 5 & 0.25 & GB & M & cat; V: amp, spl & $\mathrm{P}$ & 5.1 & & 3.7 & -40 & & & & & & \\
\hline $2 \mathrm{R}-1,0-4$ & $i$ & 9.3 & GB & $\mathrm{M}$ & $\mathrm{V}: \mathrm{amp}$ & M & 2.7 & & 3.7 & -49 & 3.0 (amp) & -42 & & & & \\
\hline $2 \mathrm{R}-1,51-54$ & 7 & 9.81 & $\mathrm{~GB}$ & $\mathrm{~F}$ & cat & $\mathrm{P}$ & & & & & & & 2.5 & & & \\
\hline $2 \mathrm{R}-1,51-54$ & 7 & 9.81 & GB & $\mathrm{VF}$ & ucat SZ & $\mathrm{P}$ & & & & & & & 6.2 & -56 & & \\
\hline $3 \mathrm{R}-1,15-20$ & 4 & $\begin{array}{l}3.01 \\
16.95\end{array}$ & GB & $\mathrm{M}$ & cat; V: pre, ep & H-P & 8.3 & & 5.3 & -49 & & & 0.2 & -50 & & \\
\hline $3 R-1,45-50$ & 8 & 17.25 & MGB & $\mathrm{F}$ & cat & $\mathrm{P}$ & 9.2 & & ... & $\rightarrow 9$ & & & & & & \\
\hline $3 \mathrm{R}-1,77-83$ & 14 & 17.57 & GB & M & cat & $\mathrm{P}$ & 9.4 & & 5.5 & -34 & & & & & 0.1 & 15.9 \\
\hline \multicolumn{17}{|l|}{ 147-894G- } \\
\hline $2 \mathrm{R}-3,51-53$ & 6 & 32.06 & OL GB & M & pcat, V: chl, sm, pre & P & 9.1 & & 4.3 & -46 & $7.4(\mathrm{sm})$ & -35 & & & & \\
\hline $2 \mathrm{R}-3,51-53$ & 6 & 32.06 & $\mathrm{OLGB}$ & VF-F & cat SZ & $\mathrm{P}$ & 4.9 & & & & & & & & & \\
\hline $4 \mathrm{R}-2,52-54$ & $9 \mathrm{~A}$ & 46.86 & GN & M & $\mathrm{V}: \mathrm{sm}, \mathrm{cc}$ & M & 4.5 & & 5.2 & -54 & $8.2(\mathrm{chl} / \mathrm{sm})$ & & & & & \\
\hline $6 \mathrm{R}-1,3 \mathrm{I}-34$ & $4 \mathrm{C}$ & 55.11 & $\mathrm{GN}$ & $\mathrm{M}$ & $\mathrm{V}: \mathrm{chl} / \mathrm{sm}$ & $\mathrm{M}-\mathrm{H}$ & 8.8 & & 5.5 & -55 & $4.4(\mathrm{chl} / \mathrm{sm})$ & & & & & \\
\hline $6 \mathrm{R}-1,120-124$ & 10 & 56 & $\mathrm{GN}$ & $\mathrm{M}-\mathrm{C}$ & cat: $\mathrm{V}:$ pre, act, chl, sm & $\mathrm{H}$ & 8.3 & & 5.3 & -53 & & & & & & \\
\hline $6 \mathrm{R}-1,131-137$ & 12 & 56.11 & GN & M & $\mathrm{V}$ : pre, cor; halo & $\mathrm{H}-\mathrm{P}$ & & & & & $9.4(\mathrm{sm})$ & & & & & \\
\hline $8 \mathrm{R}-1,10-13$ & 2 & 68.6 & $\mathrm{GN}$ & $\mathrm{M}$ & $\mathrm{V}: \mathrm{chl} / \mathrm{sm}$ & $\mathrm{M}-\mathrm{P}$ & & & & & $1.6(\mathrm{chl} / \mathrm{sm})$ & & & & & \\
\hline $8 \mathrm{R}-1,47-50$ & $5 \mathrm{~A}$ & 68.97 & $\mathrm{GN}$ & $\mathrm{F}$ & cat; V: pre; chl, chl/sm, halo & $\mathrm{P}$ & 9.5 & & & & & & & & & \\
\hline $8 R-1,47-50$ & $5 \mathrm{~A}$ & 68.97 & $\mathrm{GN}$ & $\mathrm{M}$ & less altered part & M-P & 9.1 & & & & & & & & & \\
\hline $8 \mathrm{R}-1,143-146$ & 11 & 69.93 & GN & $\mathrm{M}$ & V: pre, chl/sm; halo & $\mathrm{H}-\mathrm{P}$ & 9.2 & & & & & & & & & \\
\hline $9 R-2,58-62$ & 3 & 76.23 & $\mathrm{GN}$ & $\mathrm{C}$ & V: amp & $\mathrm{H}$ & 4.6 & & 2.2 & -52 & & & & & & \\
\hline $10 \mathrm{R}-1,56-60$ & $11 \mathrm{~A}$ & 79.66 & $\mathrm{~GB}$ & $\mathrm{M}$ & $\mathrm{V}: \mathrm{chl} / \mathrm{sm}$ & $\mathrm{M}$ & 5.8 & & 5.2 & -59 & & & & & & \\
\hline IIR-1,117-121 & 16 & 85.27 & $\mathrm{~GB}$ & $\mathrm{M}$ & V: pre, chl/sm & $\mathrm{M}-\mathrm{P}$ & 6.3 & & & & & & & & & \\
\hline $12 \mathrm{R}-5,17-20$ & 4 & 99.9 & GN & $\mathrm{M}-\mathrm{C}$ & cat; V: pre; halo & $\mathrm{P}$ & 9.7 & & & & & & & & & \\
\hline $12 \mathrm{R}-5,48-52$ & $7 \mathrm{~B}$ & 100.21 & GN & M & V: amp, pre, chl, chl/sm & H-P & 9.0 & & & & & & & & & \\
\hline $12 \mathrm{R}-5,48-52$ & $7 \mathrm{~B}$ & 100.21 & $\mathrm{GN}$ & $\mathrm{M}$ & halo & $\mathrm{P}$ & 9.5 & -41.9 & & & & & & & & \\
\hline $13 R-3,37-41$ & 3 & 106.6 & $\mathrm{GN}$ & $\mathrm{M}$ & $\mathrm{V}$ : chl, cor & M & & & & & $3.0($ cor $/ \mathrm{chl})$ & & & & & \\
\hline $20 \mathrm{R}-2,1-3$ & i & 147.04 & GN & $\mathrm{C}$ & V: amp; pre, chl, chl/sm; halo & $\mathrm{H}$ & 10.2 & & 2.7 & -54 & & & & & & \\
\hline $20 \mathrm{R}-3,27-33$ & 5 & 147.69 & $\mathrm{GN}$ & $\mathrm{F}-\mathrm{M}$ & cat, V: pre, chl, chl/sm & $\mathrm{H}-\mathrm{P}$ & 9.4 & & 5.3 & -58 & & & & & & \\
\hline
\end{tabular}

Notes: Mineral abbreviations are: $\mathrm{plg}=$ plagioclase; $\mathrm{spl}=$ secondary plagioclase; pre = prehnite; amp = amphibole; act = actinolite; chl = chlorite; chl/sm = chlorite/smectite mixed layered clay; $\mathrm{sm}=\mathrm{smectite} ; \mathrm{cor}=$ corrensite $(<2 \mu \mathrm{n}$ size fraction): $\mathrm{ep}=$ epidote; $\mathrm{cc}=$ calcite. Lithology abbreviations: $\mathrm{OL} \mathrm{GB}=$ olivine gabbro; $\mathrm{GB}=$ gabbro; $\mathrm{GN}=$ gabbronorite; $\mathrm{MGB}=$ metagabbro. Relative grain sizes denoted as: $\mathrm{C}=5$ to $10 \mathrm{~mm} ; \mathrm{M}=1$ to $5 \mathrm{~mm} ; \mathrm{F}=<1 \mathrm{~mm} ; \mathrm{VF}$

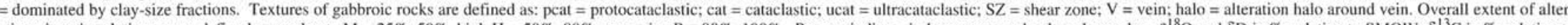
ation given in relative terms, defined as moderate $\mathrm{M}=25 \%-50 \%$, high $\mathrm{H}=50 \%-80 \%$, pervasive $\mathrm{P}=80 \%-100 \%$. Ranges indicate imhomogeneously altered samples. $\delta{ }^{18} \mathrm{O}$ and $\delta \mathrm{D}$ in \%o relative to $\mathrm{SMOW} ; \delta^{3} \mathrm{C}$ in \%o relative to 


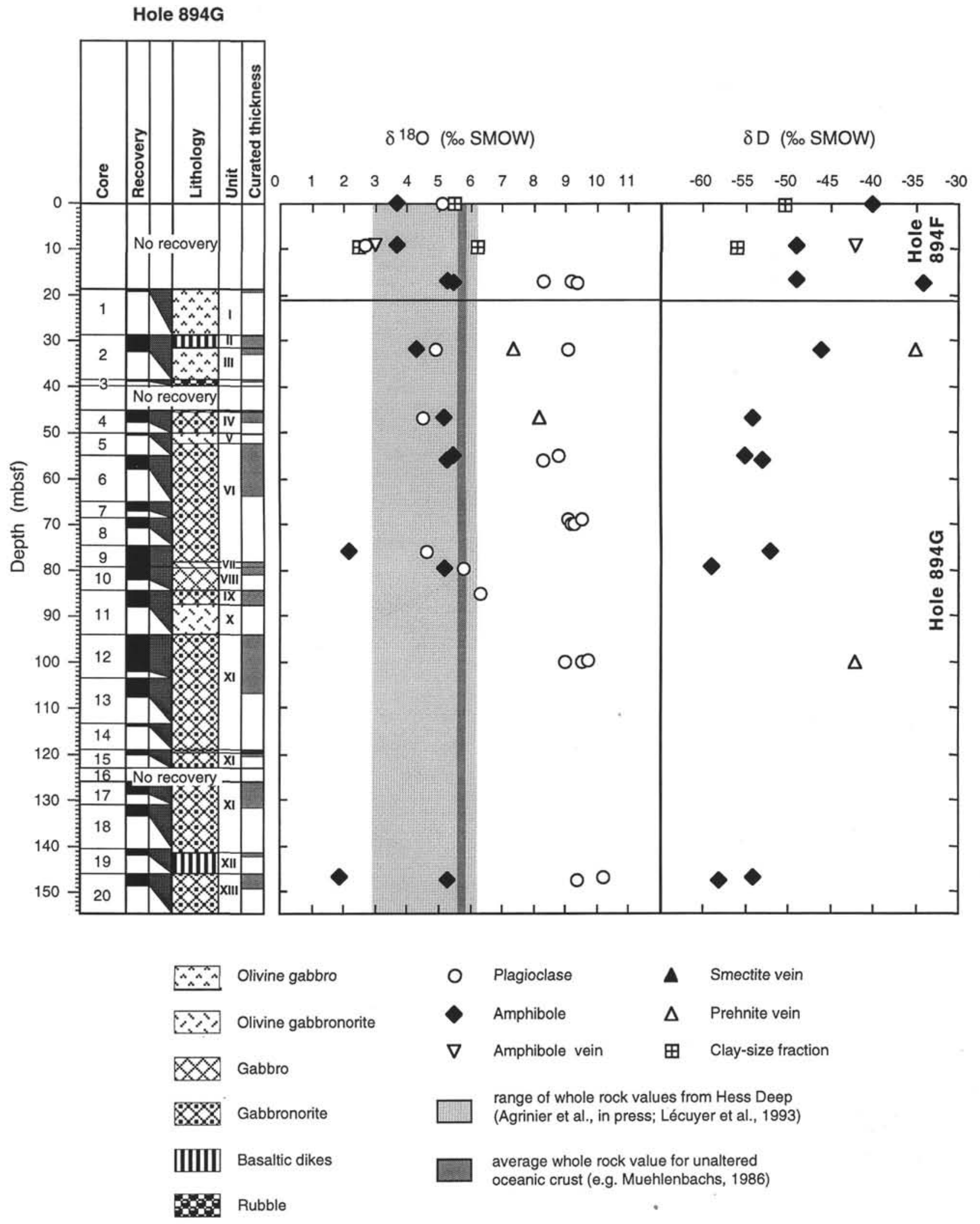

Figure 11. Variations in oxygen and hydrogen isotope ratios of mineral separates plotted as a function of depth in Holes $894 \mathrm{~F}$ and $894 \mathrm{G}$. 


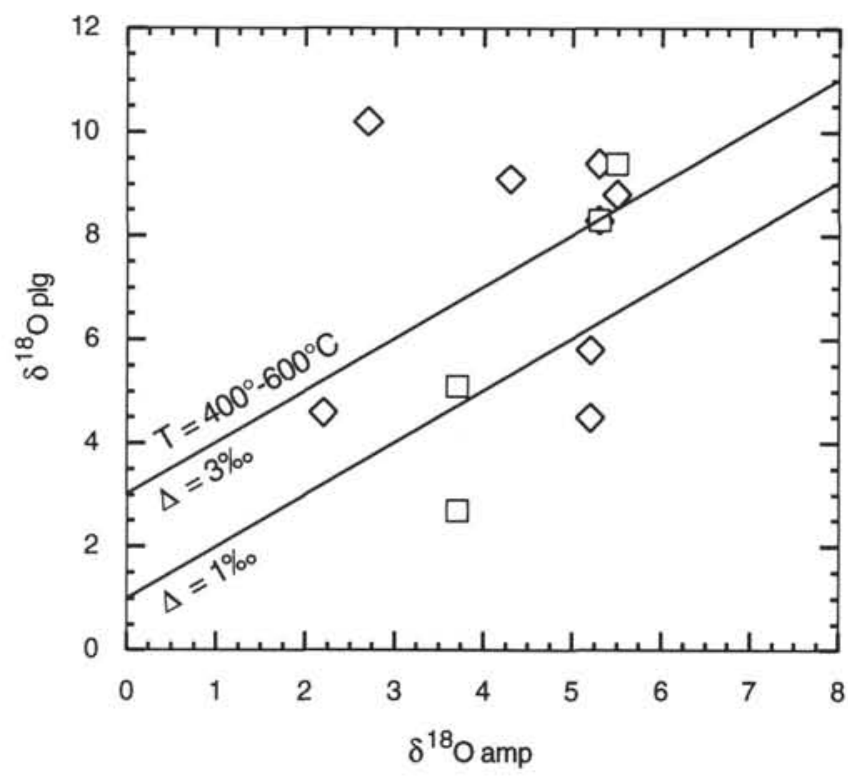

Figure 12. Oxygen isotope ratios for coexisting plagioclase (plg) and amphibole (amp) pairs from Hole 894F (squares) and Hole 894G (diamonds). Compositions reflecting equilibrium at near igneous temperatures (i.e., $>800^{\circ} \mathrm{C}$ ) would be expected to plot close to the line indicated by $\Delta=$ $1 \%$, whereas equilibrium at lower temperatures of $400^{\circ}-600^{\circ} \mathrm{C}$ results in high $\Delta$ values between $2 \%$ and $3 \%$ and will be reflected by a linear array of values below the line indicated by $\Delta=3 \%$. Data plotting outside these fields indicate open system disequilibrium conditions at varying fluid/rock ratios.

line and an equilibrium line of $\Delta=3.0$ for temperatures of $400^{\circ} \mathrm{C}$ as shown in Figure 12 (e.g., Gregory and Criss, 1986). Equilibrium at lower temperatures would produce similar linear arrays above the $\Delta$ $=3.0$ line (i.e., corresponding to larger $\delta$ values of the coexisting pairs). The majority of the plagioclase-amphibole pairs from Site 894 fall either below the igneous equilibrium band or above the $400^{\circ} \mathrm{C}$ equilibrium band, emphasizing the overall disequilibrium conditions characteristic of open system exchange.

\section{Hydrogen Isotope Ratios}

The hydrogen isotope compositions of the hydrous phases in the gabbros provide additional information about the nature of the hydrothermal fluids that exchanged with these rocks. A compiled profile of the $\mathrm{D} / \mathrm{H}$ ratios of $\mathrm{Ca}-\mathrm{Al}$ amphibole, corrensite $(<2 \mu \mathrm{m}$ size fractions $)$ and vein-fillings from the gabbroic section in Holes 894F and $894 \mathrm{G}$ are shown as a function of depth in Figure 11. The hydrogen isotope ratios of amphibole form two groups: a deuterium-rich group with $\delta \mathrm{D}$ values between approximately $-49 \%$ and $-35 \%$ in the upper part of the section; and a deuterium-depleted group with $\delta \mathrm{D}$ values between approximately $-60 \%$ and $-52 \%$ below $\approx 35 \mathrm{mbsf}$. Although experimental data on the $\mathrm{D} / \mathrm{H}$ fractionation between hydrous minerals and water is scanty and commonly contradictory, this distinction in $\delta \mathrm{D}$ values implies two slightly different sources of the hydrothermal fluids. Experimental studies indicate that hydrogen fractionation between amphibole and water is dependent on mineral chemistry, particularly with regard to octahedral cation distributions in the M1 and M3 sites and substitutions in the A sites (Suzuoki and Epstein, 1976; Graham et al., 1984). However, these studies indicate that over a temperature range of $400^{\circ}-650^{\circ} \mathrm{C}$, actinolitic to hornblenditic amphiboles will generally have equilibrium $\mathrm{D} / \mathrm{H}$ ratios that are approximately $-45 \%$ o to $-23 \%$ o lower than their coexisting waters. Thus, the D-depleted compositions of amphibole in the lower part of the section indicate that the hydrothermal fluids could not have been pure seawater (i.e., with a $\delta \mathrm{D}$ value of $0 \pm 5 \%$ ), but were significantly de-

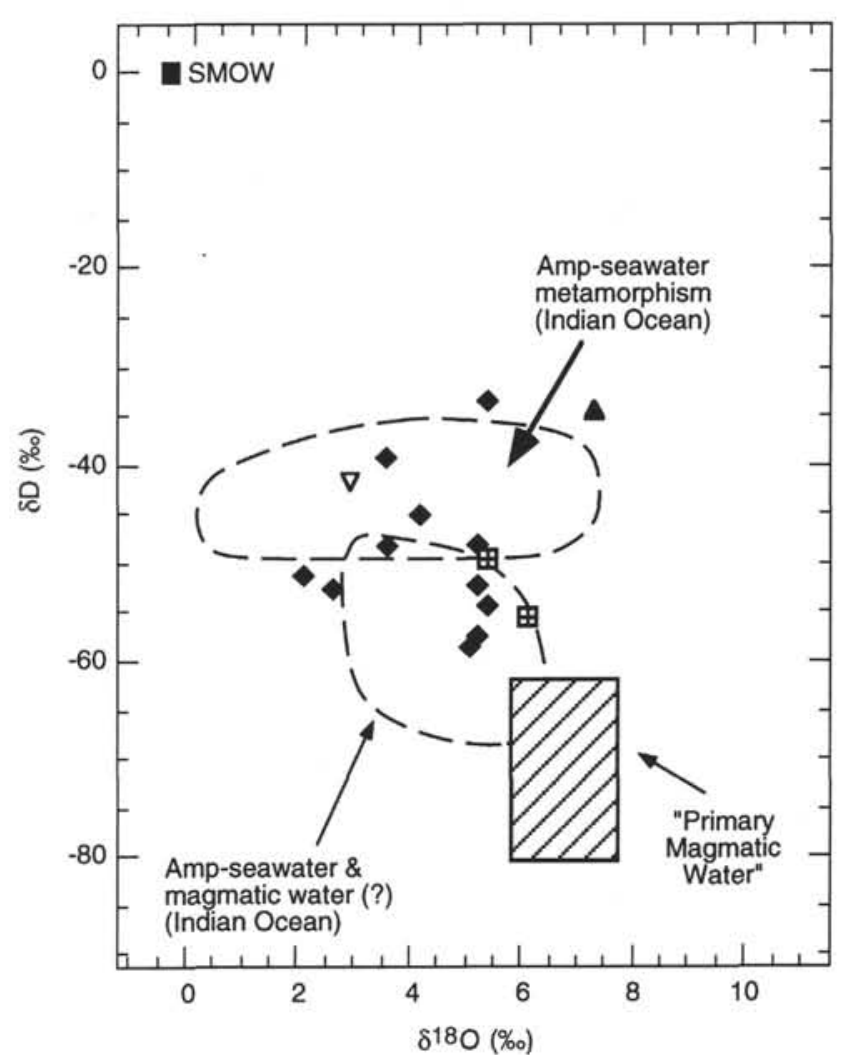

Figure 13. Hydrogen and oxygen isotope ratios of amphibole (diamonds), amphibole veins (upside-down open triangle), smectite veins (solid triangle), and clay-sized fraction dominated by corrensite (divided squares) from Site 894 compared with equilibrium fields for hornblende during seawater metamorphism and seawater + magmatic water (?) metamorphism, defined by Stakes (1991) from Indian Ocean plutonic rocks.

pleted in deuterium relative to seawater and suggest a deuterium-poor component in the hydrothermal fluids. The exact source of this additional component cannot be determined unequivocally; both magmatic volatiles and "metamorphic" fluids derived from dehydration reactions would be deuterium-poor and ${ }^{18} \mathrm{O}$-rich relative to seawater. Although metamorphic dehydration reactions cannot be ruled out at Hess Deep, we consider magmatic volatiles to be a more plausible source and, as discussed below, is consistent with other trace element and fluid inclusion studies (e.g., Gillis, this volume; Kelley and Malpas, this volume). Thus, the variation in hydrogen isotope compositions with depth may reflect the paths of the two components of the hydrothermal fluids, with a flux of magmatic volatiles from below and mixing with evolved, seawater-dominated hydrothermal fluids descending from higher levels in the oceanic crust. A similar variation with depth, characterized by decreasing $\delta D$ values of serpentine is also observed in Hole 895E (Früh-Green et al., this volume) and suggests that a contribution from processes of magma-degassing (and/or dehydration reactions) was significant during alteration of the EPR oceanic lithosphere.

In Figure 13, the hydrogen and oxygen isotope ratios of the hydrous minerals at Site 894 are compared with isotopic compositions of amphibole in gabbros from the Indian Ocean (Stakes, 1991; Kempton et al., 1991; Früh-Green et al., this volume). On the basis of stable isotope ratios of amphibole from Indian Ocean plutonic rocks, Stakes (1991) defines two fields of isotopic compositions during hydrothermal metamorphism of the lower ocean crust at temperatures of $400^{\circ}-$ $500^{\circ} \mathrm{C}$, corresponding to a seawater-dominated source and a mixed modified seawater-magmatic water source of the hydrothermal fluids. 
The isotopic compositions of the Site 894 amphiboles scatter between these two fields and are comparable to those of the Indian ocean amphiboles, indicating high temperature alteration in a rock-dominated system. The variations in the hydrogen isotope ratios in the Site 894 $\mathrm{Ca}-\mathrm{Al}$ amphiboles suggests that the isotopic composition of the hydrothermal fluids may not have been homogeneous over the entire upper amphibolite-greenschist facies alteration history of the lower crust at Hess Deep and may reflect episodes in which contributions from a low $\delta \mathrm{D} /$ high $\delta^{18} \mathrm{O}$ magmatic component in the fluid were greater.

The oxygen and hydrogen isotope ratios of the two corrensites in the cataclastic shear zones from Holes $894 \mathrm{~F}$ are also surprisingly low ( $5.5 \%$ to $6.2 \%$ and $-56 \%$ to $-50 \%$, respectively) for equilibrium with a pure seawater source. However, considering the fact that brittle deformation occurred late in the tectonic/hydrothermal history of Hess Deep (see below), a seawater source of the hydrothermal fluids is most plausible. Therefore, these values may reflect compositions inherited from the precursor minerals and would imply that crystallization took place at the upper stability limits for corrensite (approximately $200^{\circ}-250^{\circ} \mathrm{C}$ ) and low fluid-rock (F/R) ratios (below volumetric F/R values of approximately 0.01 ; see e.g., Criss and Taylor, 1986). Relatively high temperatures of vein formation are also indicated by the oxygen isotope ratios of the vein-filling phases in the Hole 894G gabbros (Table 2). By applying theoretical, bond-type fractionation curves (Savin and Lee, 1988; Früh-Green, unpubl. data) as an approximation of temperatures of clay formation in the veins, the relatively negative $\delta^{18} \mathrm{O}$ values of smectite, chlorite, and mixed-layered smectite/chlorite indicate temperatures between $160^{\circ}$ and $270^{\circ} \mathrm{C}$.

In general, the stable isotope data in this study support the original models of ${ }^{18} \mathrm{O}$ buffering during hydrothermal alteration of the oceanic lithosphere; however low temperature retrograde alteration may mask early processes of high temperature isotopic exchange. We further suggest that magmatic processes and magma-degassing may have played an important role in the high temperature phase of hydrothermal alteration at Hess Deep.

\section{DISCUSSION}

The initial results of Leg 147 have shown that the basaltic and gabbroic rocks recovered at Site 894 provide new constraints on the interaction of magmatic, tectonic and hydrothermal processes in a fast-spreading environment (Gillis, Mével, Allan, et al., 1993; Shipboard Scientific Party, 1993a, 1993b). Our study of the Site 894 plutonic rocks presents mineralogic and stable isotope data that document a complex polyphase history of fluid infiltration, metamorphism, and deformation from late magmatic activity through upper amphibolite facies to zeolite facies conditions. Metamorphism is dominated by hydration reactions and static, pseudomorphic replacement of the primary igneous phases. The overall degree of alteration and the distribution of lower temperature mineral assemblages is related to an increase in cataclastic deformation and the density of chlorite-rich veins.

Early high-temperature $\left(>500^{\circ} \mathrm{C}\right)$ infiltration of seawater and hydrothermal alteration in the Site 894 gabbroic rocks produced metamorphic assemblages of hornblenditic amphibole, secondary diopside, secondary calcic plagioclase, ilmenite, and magnetite. Penetration of seawater was controlled by grain boundary geometries and microfractures created during cooling of the oceanic lithosphere, resulting in a low $\delta^{18} \mathrm{O}$ sequence early in the tectonic history of the Hess Deep. Halite-bearing, locally $\mathrm{CO}_{2}$-rich, plagioclase- and apatite-hosted fluid inclusions in coarse-grained patches of gabbronorite suggest that the earliest hydrothermal fluids contained magmatic fluids exsolved from residual pockets of evolved interstitial melt (Gillis, Mével, Allan, et al., 1993; Kelley and Malpas, this volume). A magmatic component in the early hydrothermal fluids is consistent with deuterium-depleted hydrogen isotope ratios of amphibole in the Site 894 gabbros and with differences in rare earth element (REE) pat- terns in clinopyroxene/amphibole pairs reported by Gillis (this volume). This suggests that the gabbroic section recovered at Site 894 may represent a distinct alteration zone that marks the boundary between down-welling, evolved seawater-dominated hydrothermal fluids and an upward flux of late magmatic volatiles during cooling and contraction of oceanic layer 3. Although the fluid components are different, this type of transitional mixing zone may be similar to subsurface mixing zones documented in Hole 504B, in which hot hydrothermal fluids, upwelling along fractures in the dike section, encounter large volumes of cooler seawater circulating in the upper pillow section (Alt et al., 1986a). At Hole 504B, interaction between these two fluids has created a metamorphic boundary between low-temperature alteration in the pillow section and greenschist facies assemblages in the dikes.

The intensity of high-temperature alteration at Site 894 is related to the density of early amphibole-filled microfractures and tends to be greater in the coarser-grained rocks. This relationship suggests that the rheologies of the rocks controlled fluid pathways and that microfracture permeabilities were greater in the coarse-grained portions of the section. The presence of coarse-grained euhedral amphibole in these pegmatitic zones remains puzzling. The textures and the association with apatite, zircon, and titanite suggest a late magmatic (deuteric) origin. Therefore, exsolution of magmatic volatiles trapped in residual evolved melts may have also played a significant role in the early phases of alteration of these coarse-grained zones. Interestingly, the lowest $\delta^{18} \mathrm{O}$ values were measured in highly altered, amphibolite facies coarse-grained gabbronorites (Table 2) and may imply a local, relative increase in fluid/rock ratios associated with enhanced permeabilities during the high-temperature phase of metamorphism. However, the heterogeneous distribution of high-temperature alteration assemblages as well as the variations in hydrogen and isotope ratios in amphibole throughout the section reflect overall rock-dominated conditions of alteration. The presence of amphibole-filled microfractures associated with high-temperature mineral assemblages, as well as the chemical and isotopic compositions of the amphiboles, indicate that the migration of seawater and mixing with magmatic volatiles occurred in the deep-seated gabbro section at temperatures in excess of $500^{\circ} \mathrm{C}$ at an early stage in the cooling and contraction history of the East Pacific Rise (see also Manning and MacLeod, this volume; Gillis, this volume).

Progressive cooling during transport away from the EPR, combined with tectonic processes related to the propagation of the CocosNazca ridge, enhanced fracture permeabilities and the penetration of seawater-dominated hydrothermal fluids into the oceanic crust. Fluid circulation through fractures led to the development of a pervasive network of chlorite-rich veins and greenschist to zeolite facies mineral assemblages in the gabbros. Multiple generations of discrete veins composed of chlorite with varying proportions of prehnite, mixed-layered clays, epidote, sphene, calcite (or dolomite), and secondary feldspar (albite and K-feldspar) are associated with secondary alteration in the wall rocks, dominated by the breakdown of plagioclase to albitic plagioclase \pm prehnite \pm epidote \pm calcite \pm clays. Wall-rock alteration is extensive where vein densities are high and veining has produced complex brecciated and cataclastic fabrics (Figs. 3 through 5). TEM studies indicate that cracks and grain boundaries at all scales provide pathways for the infiltration of aqueous fluids and therefore, serve as nucleation sites for chemical alteration (Fig. 8). The studies of Kelley and Malpas (this volume) on secondary, liquid-dominated fluid inclusions in plagioclase associated with the wall-rock alteration around chlorite-prehnite veins imply a seawater source of the hydrothermal fluids with low salinities similar to salinities measured in present-day hydrothermal vents. The presence of epidote, prehnite, and calcite as vein-filling phases and alteration products of plagioclase suggest off-axis circulation of evolved $\mathrm{Ca}$-rich hydrothermal fluids (low $\mathrm{Mg} / \mathrm{Ca}$ ratios, relatively high $\mathrm{pH}$ ) and is consistent with fluid compositions predicted from experiments and computer modelling of the alteration of basalts (e.g., Mottl, 1983; 
Bowers and Taylor, 1985; Seyfried et al., 1988). Fluid compositions during this phase of veining may thus have been similar to vent fluids sampled from present-day ridges (e.g., Von Damm et al., 1985).

Further evidence of off-axis, Cocos-Nazca-dominated fracturing and fluid infiltration at temperatures below $250^{\circ} \mathrm{C}$ is indicated by latestage fractures filled with chlorite, smectite-rich clays, calcite, and locally $\mathrm{Na}-\mathrm{Ca}$ zeolites and by positive shifts in the oxygen isotope ratios in plagioclase. Alteration and precipitation of phyllosilicates at temperatures between $150^{\circ}$ and $250^{\circ} \mathrm{C}$ is particularly well-developed in the shallow zones of cataclasis in Holes $894 \mathrm{~F}$ and $894 \mathrm{G}$. Crosscutting relationships between the chlorite-rich veins and cataclastic deformation indicate a complex, continuous history of deformation and infiltration of fluids with varying chemical compositions. The shallow cataclastic zones are cut by veins filled with chlorite + prehnite \pm calcite or zeolites, indicating that some episodes of chlorite-prehnite veining post-date cataclasis. However, local irregularly deformed patches of chlorite and disrupted prehnite clasts in the clay-rich cataclastic matrix of some samples also indicates that some phases of chlorite and prehnite crystallization occurred prior to or during the main shearing event. Thus, these sections have been affected by varying pulses of evolved Ca-rich fluids during the late stages of off-axis alteration and deformation. The mineralogies of the phyllosilicates in the matrix of the cataclasites are dominated by mixtures of chlorite and chlorite/ smectite clays and may imply a local source of $\mathrm{Mg}$ through the alteration of pyroxene and amphibole. However, a two component fluid can also be envisioned: $\mathrm{Mg}$-rich downwelling seawater; and upwelling, evolved hydrothermal fluids. Mixing of these fluids may have produced a "mixed" reducing hydrothermal fluid that deposited the chlorite/smectite clays and pyrite observed in Hole $894 \mathrm{~F}$ and the upper part of Hole $894 \mathrm{G}$. These assemblages and fluid compositions are comparable with alteration assemblages in the hydrothermal vent region of the sedimented ridge at Middle Valley, northern Juan de Fuca Ridge (Buatier et al., 1994). At Middle Valley, direct deposition of $\mathrm{Mg}$-rich chlorite and regular mixed-layered chlorite/smectite clays are associated with semi-massive sulfides in a zone of discharging reducing fluids (Früh-Green et al., 1994; Früh-Green, unpubl. data). Multiple phases of deformation and alteration, with varying fluid sources and mixing of hydrothermal fluids, is well documented in the studies of Hole 504B (Alt et al., 1986a, 1986b; Kawahata et al., 1987). These studies of Hole 504B have shown that mineralogies and isotopic signatures in the upper oceanic crust record a complex history of deformation and hydrothermal processes at progressive distances away from the ridge axis, and may provide an approximate analog to the off-axis hydrothermal evolution at Hess Deep.

The absence of penetrative crystal plastic deformation at Site 894 is in marked contrast to the highly ductile deformation style observed in Site 735B gabbros from the slow-spreading Southwest Indian Ridge and gabbros at the Mid-Atlantic Ridge (Mével and Cannat, 1991; Cannat et al., 1991; Dick et al., 1991; Stakes et al., 1991). Two mechanisms of deformation are apparent in the Hess Deep gabbroic section: strain localization and cataclastic shearing at shallow levels; and brecciation and cataclasis related to fluid overpressures in local zones of dense veining (i.e., hydrothermal brecciation). Multiple phases of opening and filling of fractures are indicated by the zoned nature of the chlorite-prehnite veins and rare distinct crack-seal textures. The dominant west-northwest-east-southeast orientation of the chlorite/prehnite and smectite/zeolite veins suggests that the major episode of veining and associated fluid-rock interaction was controlled by processes of crustal attenuation and faulting related to the propagation of the Cocos-Nazca ridge and the ultimate formation of the Hess Deep Rift Valley (Shipboard Scientific Party, 1993a, 1993b; MacLeod et al., 1993; MacLeod, Célérier, et al., this volume; Célérier and MacLeod, this volume). We interpret the development of the cataclasites to ultracataclasites at shallow depths as a consequence of this phase of relatively fast uplift and faulting (compared to Hole $735 \mathrm{~B}$ ), ultimately exposing the gabbros on the ocean floor. Uplift associated with faulting may have brought this section of layer 3 into a crustal level where mixing of downwelling $\mathrm{Mg}$-rich fluids and upwelling evolved hydrothermal solutions resulted in the precipitation of chlorite-rich phyllosilicates and Fe-sulfides in the cataclastic zones. Subsequent episodes of off-axis fracturing allowed the infiltration of further pulses of evolved Ca-rich fluids and led to the deposition of prehnite, calcite, and zeolites in veins that crosscut the cataclastic fabrics.

The complex history of deformation and hydrothermal alteration over a large range in temperatures is particularly well recorded by the oxygen isotope data. In contrast to oxygen isotope profiles in ophiolite sequences and the upper oceanic crust at 504B (see Alt et al., 1986b; and review in Muehlenbachs, 1986), the Site 894 gabbros do not show a simple ${ }^{18} \mathrm{O}$ depletion characteristic of high-temperature alteration in sheeted dike complexes and lower crustal gabbroic and ultramafic sections. $\delta^{18} \mathrm{O}$ values of plagioclase in the Site 894 gabbros form two distinct groups. The values reflect: (1) high-temperature alteration $\left(400^{\circ}-600^{\circ} \mathrm{C}\right)$ resulting in a general ${ }^{18} \mathrm{O}$-depletion; followed by (2) progressive retrograde exchange during low temperature $\left(\angle 250^{\circ} \mathrm{C}\right)$ deformation and hydrothermal alteration at variable, and possibly higher, fluid/rock ratios. The latter stage of alteration resulted in significant enrichments in ${ }^{18} \mathrm{O}$ and a shift back to positive values similar to or higher than the original magmatic values. The enrichment in ${ }^{18} \mathrm{O}$ in the plagioclase is local and can be directly correlated with a higher degree of lower greenschist to zeolite facies overprinting and albitization associated with brittle deformation in the gabbroic section and the formation of the discrete vein sets. Retrograde overprinting is related to the tectonic history specific to Hess Deep and may not be representative of oxygen isotope exchange in general at fast-spreading ridges. In contrast, the early high-temperature alteration can be related to near-axial, EPR hydrothermal processes. As discussed above, we have argued that seawater penetrated to deeper levels of oceanic layer 3 and has produced a low $\delta^{18} \mathrm{O}$ sequence early in the tectonic history of Hess Deep. Such processes may, thus, be more representative of oxygen isotope exchange at fast-spreading ridges and are consistent with isotope studies of the shallow mantle sequences at Site 895 (Früh-Green et al., this volume).

The results of this study suggest that caution may be warranted in the interpretation of whole rock data from altered gabbros. Late stage overprinting of plagioclase can produce higher whole rocks $\delta$ values that mask early high temperature events and do not record the full history of isotopic exchange in the rocks. This has major consequences when considering the contribution of alteration of oceanic layer 3 to the overall ${ }^{18} \mathrm{O}$ mass balance between seawater and the oceanic crust. Mass balance calculations of the ${ }^{18} \mathrm{O}$ budget between seawater and the oceanic crust must therefore take into account modal amounts of primary and secondary phases and their isotopic compositions, as well as the overall alteration and deformation history of the area being studied.

\section{SUMMARY AND CONCLUSIONS}

Alteration of the high level gabbros recovered at Site 894 occurred through several stages of fracturing and fluid infiltration during progressive transport of the oceanic crust away from the axis of the EPR and ultimate intersection with the Cocos-Nazca propagator. Alteration was controlled by fracture permeabilities, grain-size geometries, and the chemical composition of progressive pulses of hydrothermal fluids. The metamorphic/hydrothermal alteration history recorded in the Site 894 gabbroic section is generalized by the following sequence.

1. Early, near-axis high temperature $\left(>500^{\circ} \mathrm{C}\right)$ fluid infiltration and static metamorphism produced amphibolite-facies assemblages and a depletion in ${ }^{18} \mathrm{O}$ throughout the section. Fluid penetration and alteration was controlled by grain boundary geometries and microfractures created during cooling and contraction of the oceanic crust. Hydrogen isotope ratios indicate mixing of two fluid sources: (1) 
evolved hydrothermal fluids; and (2) magmatic volatiles released during late stage crystallization of evolved interstitial melts (see Gillis, this volume; Kelley and Malpas, this volume).

2. Progressive cooling and contraction during transport away from the EPR enhanced fracture permeabilities and penetration of seawater-dominated hydrothermal fluids into the oceanic crust until tectonic processes related to the propagation of the Cocos-Nazca spreading center become dominant. Fluid infiltration at temperatures of $200^{\circ}-350^{\circ} \mathrm{C}$ led to the development of a pervasive west-northwest-east-southeast oriented network of chlorite-rich veins and alteration to greenschist to zeolite facies mineral assemblages in the wall rocks (Kelley and Malpas, this volume; MacLeod, Manning, et al., this volume).

Alteration was dominated by evolved Ca-rich hydrothermal fluids (low $\mathrm{Mg} / \mathrm{Ca}$ ratios, relatively high $\mathrm{pH}$ ), possibly similar to vent fluids sampled from present-day ridges (e.g., Von Damm et al., 1985).

3. Subsequent episodes of Cocos-Nazca-dominated fracturing and fluid infiltration at temperatures below $250^{\circ} \mathrm{C}$ resulted in late-stage fractures filled with chlorite, smectite-rich clays, calcite, and (locally) Na-Ca zeolites, and positive shifts in the oxygen isotope ratios in plagioclase. Rapid uplift and faulting resulted in the development of the cataclasites to ultracataclasites (now occurring at shallow depths) and the ultimate formation of the Hess Deep. Uplift and emplacement of the gabbroic section on the ocean floor may have brought this section of layer 3 into a crustal level where mixing of downwelling $\mathrm{Mg}$ rich fluids and upwelling evolved hydrothermal solutions resulted in the precipitation of chlorite-rich phyllosilicates and Fe-sulfides in cataclastic zones. Subsequent episodes of Cocos-Nazca-dominated hydrothermal activity and fracturing allowed the infiltration of further pulses of evolved Ca-rich fluids and led to the deposition of prehnite, calcite, and zeolites in veins that crosscut the cataclastic fabrics.

Although the alteration history of the EPR oceanic crust has been complicated by tectonic and hydrothermal processes specific to the propagation of the Cocos-Nazca spreading center, the metamorphic assemblages in the Site 894 gabbros record processes of hydrothermal alteration that are approximately analogous to those documented at Site 504B and in some ophiolites. Fluid mixing at magma chamber/ oceanic crust boundaries, fracture-controlled fluid infiltration and static metamorphism under upper amphibolite facies conditions may be characteristic of alteration of the lower oceanic crust at this fastspreading environment.

\section{ACKNOWLEDGMENTS}

This study was supported by ETH grant No, 0-20-710-93. We would like to thank A.M. Karpoff for SEM work, E. Reusser and P. Ulmer for assistance with microprobe analyses and interpretation of the data, U. Gerber for photographic assistance, and D. Pozzorini for keeping the lab running while G.F.G. was at sea. Without the help of A. Lamair and T. Gianettoni in sample preparation and mineral separation, this work would never have come to completion. G.F.G. would particularly like to thank the Co-Chief Scientists for their tremendous efforts during and after the cruise, and the staff and crew of the JOIDES Resolution for their patience and hard work during times of difficult drilling and for making Christmas and New Year's at sea enjoyable. We would also like to thank P. Schiffman and an anonymous reviewer for their constructive and helpful reviews.

\section{REFERENCES}

Agrinier, P., Hekinian, R., Bideau, D., and Javoy, M., in press. Stable isotope compositions $\left({ }^{18} \mathrm{O} /{ }^{16} \mathrm{O}, \mathrm{D} / \mathrm{H}\right.$, and $\left.{ }^{13} \mathrm{C} /{ }^{12} \mathrm{C}\right)$ of oceanic crust and upper mantle rocks exposed in the Hess Deep near the Galapagos Triple Junction. Earth Planet. Sci. Lett.

Agrinier, P., Javoy, M., and Girardeau, J., 1988. Hydrothermal activity in a peculiar oceanic ridge: oxygen and hydrogen isotope evidence in the $\mathrm{Xi}$ gaze ophiolite (Tibet, China). Chem. Geol., 71:313-335.
Alt, J.C., Honnorez, J., Laverne, C., and Emmermann, R., 1986a. Hydrothermal alteration of a $1 \mathrm{~km}$ section through the upper oceanic crust, Deep Sea Drilling Project Hole 504B: mineralogy, chemistry, and evolution of seawater-basalt interactions. J. Geophys. Res., 91:10309-10335.

Alt, J.C., Muehlenbachs, K., and Honnorez, J., 1986b. An oxygen isotopic profile through the upper kilometer of the oceanic crust, DSDP Hole 504B. Earth Planet. Sci. Lett., 80:217-229.

Boillot, G., Grimand, S., Mauffret, A., Mougenot, D., Kornprobst, J., Mergoil-Daniel, J., and Torrent, G., 1980. Ocean-continent boundary off the Iberian margin: a serpentinite diapir west of the Galicia Bank. Earth Planet. Sci. Lett., 48:23-34.

Borthwick. J., and Harmon, R.S., 1982. A note regarding $\mathrm{ClF}_{3}$ as an alternative to $\mathrm{BrF}_{5}$ for oxygen isotope analysis. Geochim. Cosmochim. Acta, 46:1665-1668.

Bottinga, Y., and Javoy, M., 1973. Comments of oxygen isotope geothermometry. Earth Planet. Sci. Lett., 20:250-265.

Bowers, T.S., and Taylor, H.P., Jr., 1985. An integrated chemical and stableisotope model of the origin of midocean ridge hot spring systems. J. Geophys. Res., 90:12583-12606.

Buatier, M.D., Karpoff, A.-M., Boni, M., Früh-Green, G.L., and McKenzie, J.A., 1994. Mineralogic and petrographic records of sediment-fluid interaction in the sedimentary sequence at Middle Valley, Juan de Fuca Ridge, Leg 139. In Mottl, M.J., Davis, E.E., Fisher, A.T., and Slack, J.F. (Eds.), Proc. ODP, Sci. Results, 139: College Station, TX (Ocean Drilling Program), 133-154.

Cannat, M., Mével, C., and Stakes, D., 1991. Normal ductile shear zones at an oceanic spreading ridge: tectonic evolution of Site 735 gabbros (southwest Indian Ocean). In Von Herzen, R.P., Robinson, P.T., et al., Proc. ODP, Sci. Results, 118: College Station, TX (Ocean Drilling Program), 415-429.

Cocker, J.D., Griffin, B.J., and Muehlenbachs, K., 1982. Oxygen and carbon isotope evidence for sea-water-hydrothermal alteration of the Macquarie Island ophiolite. Earth Planet. Sci. Lett., 61:112-122.

Crane, K., 1985. The spacing of rift axis highs: dependence upon diapiric processes in the underlying asthenosphere. Earth Planet. Sci. Lett., 72:405-414.

Criss, R.E., and Taylor, H.P., Jr., 1986. Meteoric-hydrothermal systems. In Valley, J.W., Taylor, H.P., Jr., and O'Neil, J.R. (Eds), Stable Isotopes in High Temperature Geological Processes. Rev. Mineral., 16:373-424.

Dick, H.J.B., Meyer, P.S., Bloomer, S., Kirby, S., Stakes, D., and Mawer, C., 1991. Lithostratigraphic evolution of an in-situ section of oceanic Layer 3. In Von Herzen, R.P., Robinson, P.T., et al., Proc. ODP, Sci. Results, 118: College Station, TX (Ocean Drilling Program), 439-538.

Dunn, T., 1986. An investigation of the oxygen isotope geochemistry of the Stillwater Complex. J. Petrol., 27:987-997.

Francheteau, J., Armijo, R., Cheminée, J.L., Hekinian, R., Lonsdale, P.F., and Blum, N., 1990. 1 Ma East Pacific Rise oceanic crust and uppermost mantle exposed by rifting in Hess Deep (equatorial Pacific Ocean). Earth Planet. Sci. Lett., 101:281-295.

1992. Dyke complex of the East Pacific Rise exposed in the walls of Hess Deep and the structure of the upper oceanic crust. Earth Planet. Sci. Lett., 111:109-121.

Früh-Green, G.L., McKenzie, J.A., Boni, M., Karpoff, A.M., and Buatier, M., 1994. Stable isotope and geochemical record of convective hydrothermal circulation in the sedimentary sequence of Middle Valley, Juan de Fuca Ridge, Leg 139. In Mottl, M.J., Davis, E.E., Fisher, A.T., and Slack, J.F. (Eds.), Proc. ODP, Sci. Results, 139: College Station, TX (Ocean Drilling Program), 291-305.

Gillis, K., Mével, C., Allan, J., et al., 1993. Proc. ODP, Init. Repts., 147: College Station, TX (Ocean Drilling Program).

Graham, C.M., Harmon, R.S., and Sheppard, S.M.F., 1984. Experimental hydrogen isotope studies: hydrogen isotope exchange between amphibole and water. Am. Mineral., 69:128-138.

Gregory, R.T., and Criss, R.E., 1986. Isotopic exchange in open and closed systems. In Valley, J.W., Taylor, H.P., Jr., and O'Neil, J.R. (Eds.), Stable Isotopes in High Temperature Geological Processes. Rev. Mineral., 16:91-127.

Gregory, R.T., and Taylor, H.P., Jr., 1981. An oxygen isotope profile in a section of Cretaceous oceanic crust, Samail ophiolite, Oman: evidence for $\delta^{18} \mathrm{O}$-buffering of the oceans by deep $(>5 \mathrm{~km})$ seawater-hydrothermal circulation at mid-ocean ridges. J. Geophys. Res., 86:2737-2755.

Hawthorne, F.C., 1983. The crystal chemistry of the amphiboles. Can. Mineral., 21:174-408.

Hekinian, R., Bideau, D., Francheteau, J., Cheminée, J.L., Armijo, R., Lonsdale, P., and Blum, N., 1993. Petrology of the East Pacific Rise crust and 
upper mantle exposed in the Hess Deep (eastern equatorial Pacific). $J$. Geophys. Res, 98:8069-8094.

Ito, E., and Clayton, R.N., 1983. Submarine metamorphism of gabbros from the Mid-Cayman Rise: an oxygen isotopic study. Geochim. Cosmochim. Acta, 47:535-546.

Karson, J.A., Hurst, S.D., and Lonsdale, P.F., 1992. Tectonic rotations of dikes in fast-spread oceanic crust exposed near Hess Deep. Geology, 20:685-688.

Karson, J.A., Thompson, G., Humphris, S.E., Edmond, J.M., Bryan, W.B., Brown, J.R., Winters, A.T., Pockalny, R.A., Casey, J.F., Campbell, A.C., Klinkhammer, G., Palmer, M.R., Kinzler, R.J., and Sulanowska, M.M., 1987. Along-axis variations in seafloor spreading in the MARK area. $\mathrm{Na}$ ture, 328:681-685.

Kawahata, H., Kusakabe, M., and Kikuchi, Y., 1987. Strontium, oxygen and hydrogen isotope geochemistry of hydrothermally altered and weathered rocks in DSDP Hole 504B, Costa Rica Rift. Earth Planet. Sci. Lett., 85:343-355.

Kempton, P.D., Hawkesworth, C.J., and Fowler, M., 1991. Geochemistry and isotopic composition of gabbros from layer 3 of the Indian Ocean crust, Hole 735B. In Von Herzen, R.P., Robinson, P.T., et al., Proc. ODP, Sci. Results, 118: College Station, TX (Ocean Drilling Program), 127-143.

Leake, B.E., 1978. Nomenclature of amphiboles. Am. Mineral., 63:10231052.

Lécuyer, C., and Fourcade, S., 1991. Oxygen isotope evidence for multistage hydrothermal alteration at a fossil slow-spreading center: the Silurian Trinity Ophiolite (California, U.S.A.). Chem. Geol. (Isot. Geosci. Sect.), 87:231-246.

Lécuyer, C., Gruau, G., Reynard, B., Mével, C., and the Leg 147 Scientific Party, 1993. High-temperature diffusion of seawater through gabbroic rocks at Hess Deep Rift Valley, Leg 147. Eos, 74:653. (Abstract)

Lonsdale, P., 1988. Structural pattern of the Galapagos microplate and evolution of the Galapagos triple junctions. J. Geophys. Res., 93:1355113574.

MacDonald, K., 1987. Tectonic evolution of ridge-axis discontinuities by the meeting, linking or self-decapitation of neighboring ridge sediments. Geology, 15:993-997.

MacLeod, C.J., Boudier, F., Célérier, B., Kennedy, L.A., 1993. Structure of the lower oceanic crust in Hess Deep from ODP Leg 147 cores and borehole electrical images. Eos, 74:653-654. (Abstract)

Manning, C.E., 1993. High temperature gabbro metamorphism at Hess Deep and the root zones of EPR hydrothermal systems. Eos, 74:653. (Abstract)

McCrea, J.M., 1950. The isotopic chemistry of carbonates and a paleotemperature scale. J. Chem. Phys., 18:849-857.

Mével, C., and Cannat, M., 1991. Lithospheric stretching and hydrothermal processes in oceanic gabbros from slow-spreading ridges. In Peters, T., Nicolas, A., and Coleman, R.J. (Eds.), Ophiolite Genesis and Evolution of the Oceanic Lithosphere. Petrol. Struct. Geol., 5:293-312.

Moore, D.M., and Reynolds, R.C., Jr., 1989. X-ray Diffraction and the Identification and Analysis of Clay Minerals: Oxford (Oxford Univ. Press).

Mottl, M.J., 1983. Metabasalts, axial hot springs, and the structure of hydrothermal systems at mid-ocean ridges. Geol. Soc. Am. Bull., 94:161-180.

Muehlenbachs, K., 1986. Alteration of the ocean crust and ${ }^{18} \mathrm{O}$ history of seawater. In Valley, J.W., Taylor, H.P., Jr., and O'Neil, J.R. (Eds.), Stable Isotopes in High Temperature Geological Processes. Rev. Mineral., 16:425-444.

Muehlenbachs, K., and Clayton, R.N., 1976. Oxygen isotope composition of the oceanic crust and its bearing on seawater. J. Geophys. Res., 81:43654369 .
O'Neil, J.R., Clayton, R.N., and Mayeda, T.K., 1969. Oxygen isotope fractionation in divalent metal carbonates. J. Chem. Phys., 51:5547-5558.

Savin, S.M., and Lee, M., 1988. Isotopic studies of phyllosilicates. In Bailey, S.W. (Ed.), Hydrous Phyllosilicates (exclusive of micas). Rev. Mineral., 19:189-223.

Seyfried, W.E., Jr., Berndt, M.E., and Seewald, J.S., 1988. Hydrothermal alteration processes at mid-ocean ridges: constraints from diabase alteration experiments, hot-spring fluids and composition of the oceanic crust. Can. Mineral., 26:787-804.

Shipboard Scientific Party [ODP Leg 147], 1993a. Offset drilling pierces the Hess Deep Rift Valley. Geotimes, 93:19-21.

1993b. Pacific lower crustal and shallow mantle sections recovered. Eos, 74:297, 307.

Sinton, J.M., and Detrick, R.S., 1992. Mid-ocean ridge magma chambers. J, Geophys. Res., 97:197-216.

Stakes, D., Mével, C., Cannat, M., and Chaput, T., 1991. Metamorphic stratigraphy of Hole 735B. In Von Herzen, R.P., Robinson, P.T., et al., Proc. ODP, Sci. Results, 118: College Station, TX (Ocean Drilling Program), 153-180.

Stakes, D.S., 1991. Oxygen and hydrogen isotope compositions of oceanic plutonic rocks: high-temperature deformation and metamorphism of oceanic layer 3. In Taylor, H.P., Jr., O'Neil, J.R., and Kaplan, I.R. (Eds.), Stable Isotope Geochemistry. Spec. Publ.-Geochem. Soc., 3.

Stakes, D.S., and O'Neil, J.R., 1982. Mineralogy and stable isotope geochemistry of hydrothermally altered oceanic rocks. Earth Planet. Sci. Lett., 57:285-304.

Stakes, D.S., and Taylor, H.P., Jr., 1992. The northern Samail Ophiolite: an oxygen isotope, microprobe, and field study. J. Geophys. Res., 97:70437080.

Suzuoki, T., and Epstein, S., 1976. Hydrogen isotope fractionation between OH-bearing minerals and water. Geochim. Cosmochim. Acta, 40:12291240.

Taylor, H.P., Jr.,1977. Water/rock interactions and the origin of $\mathrm{H}_{2} \mathrm{O}$ in granitic batholiths. J. Geol. Soc. London, 133:509-558.

, 1984. Oxygen and hydrogen isotope studies of hydrothermal interactions at submarine and subaerial spreading centers. In Rona, P.A., Boström, K., Laubier, L., and Smith, K.L., Jr. (Eds.), Hydrothermal Processes at Seafloor Spreading Centers: New York (Plenum Press), 83139.

Thompson, G., 1983. Basalt-seawater interaction. In Rona, P.A., Boström, K., Laubier, L., and Smith, K.L., Jr. (Eds.), Hydrothermal Processes at Seafloor Spreading Centers: New York (Plenum), 225-278.

Tullis, J., and Yund, R.A., 1977. Experimental deformation of dry Westerly Granite. J. Geophys. Res., 82:5705-5718.

Von Damm, K.L., Edmond, J.M., Grant, B., Measures, C.I., Walden, B., and Weiss, R.F., 1985. Chemistry of submarine hydrothermal solutions at $21^{\circ}$ N, East Pacific Rise. Geochim. Cosmochim. Acta, 49:2197-2220.

Von Herzen, R.P., Robinson, P.T., et al., 1991. Proc. ODP, Sci. Results, 118: College Station, TX (Ocean Drilling Program).

Whitehead, J.A., Dick, H.J.B., and Shouten, H., 1984. A mechanism for magmatic accretion under spreading centers. Nature, 312:146-148.

\footnotetext{
Date of initial receipt: 3 August 1994

Date of acceptance: 27 April 1995

Ms 147SR-015
} 

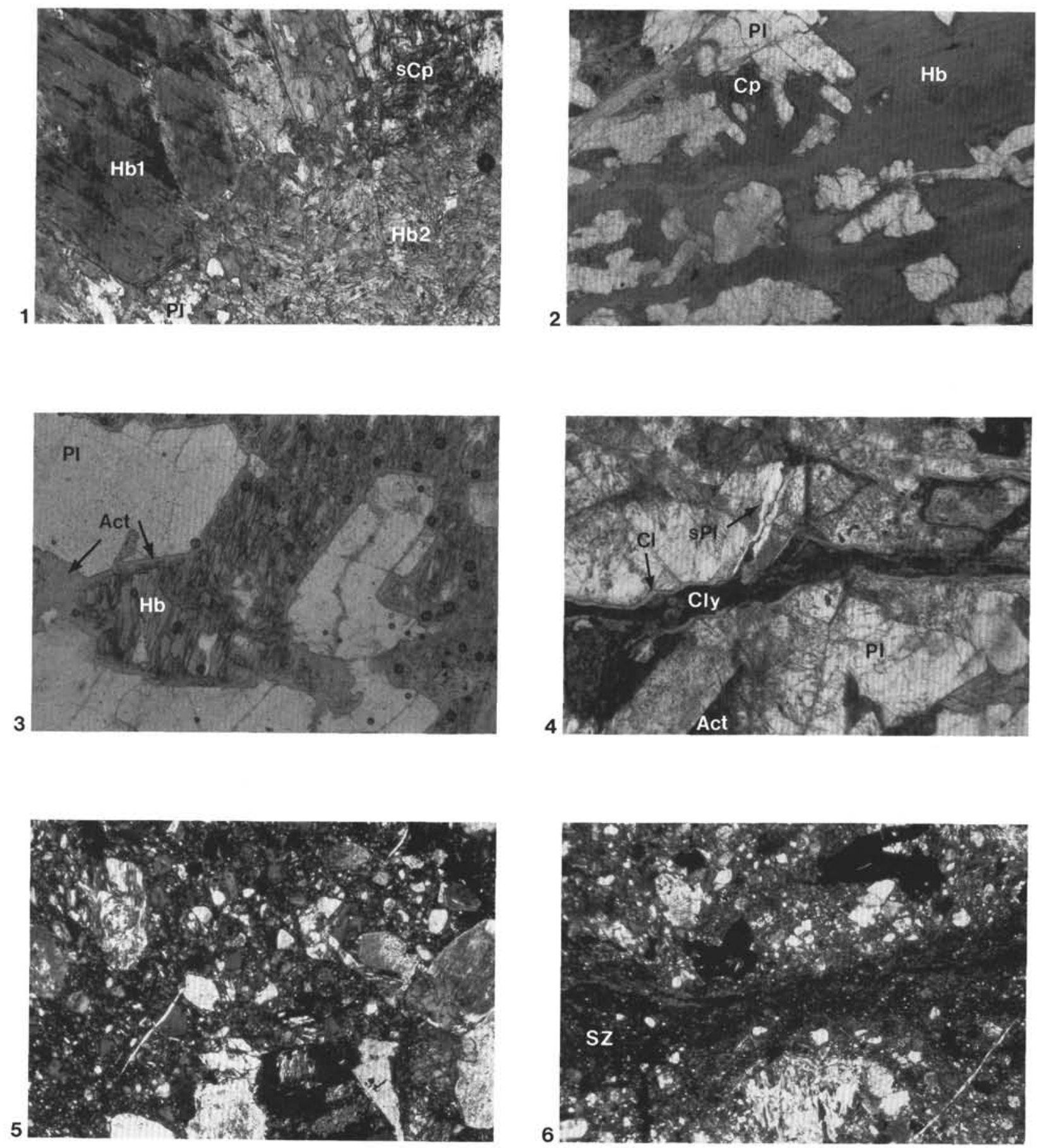

Plate 1. Photomicrographs of reaction and deformation textures. 1. Two phases of hornblende ( $\mathrm{Hb}$ ) intergrown with secondary clinopyroxene (sCp) and secondary calcic plagioclase (Pl) in coarse-grained gabbronorite Sample 147-894G-9R-2, Piece 3, 58-62 cm. Hbl are yellow-to dark-green pleochroic and have subhedral forms and well-defined cleavage. $\mathrm{Hb} 2$ have green pleochroism and form finer-grained fibrous aggregates after primary pyroxene. Width of photograph is $1.43 \mathrm{~mm}$. 2. Characteristic alteration associated with Type 1 green pleochroic amphibole veins, with hornblenditic $(\mathrm{Hb})$ replacement of primary clinopyroxene (Cp) in Sample 147-894F-2R-1, Piece 1, 0-4 cm. Relict Cp grains are typically turbid in appearance; whereas plagioclase grains (PI) appear fresh. Width of photograph is $5.63 \mathrm{~mm}$. 3. Complex, polyphase pseudomorphic replacement of pyroxene by hornblenditic amphibole (Hb) with rims of light green actinolite (Act) in gabbronorite Sample 147-894G-4R-2, 52-54 cm. Plagioclase (PI) grains remain fresh except in the vicinity of microfractures. Width of photograph represents $3.6 \mathrm{~mm}$. 4. Typical wall-rock alteration associated with zoned Type 2 and 3 veins in medium-grained gabbronorite Sample 147-894G-6R-1, Piece 10, $120-124 \mathrm{~cm}$. Plagioclase grains (PI) become turbid and are replaced by secondary albitic plagioclase. A fine rim of light green chlorite $(\mathrm{Cl})$ lines the vein walls, with dark clays (Cly) filling the centers. Filled microfractures with varying mineralogies (e.g., clear secondary plagioclase [sPI]) are associated with the main vein, cutting neighboring grains or following grain boundaries. Width of photograph represents $5.63 \mathrm{~cm}$. 5. Sample 147-894F-3R-1, Piece 9, 51-56 cm; and 6. Sample 147-894F-3R-1, Piece 4, 15-20 cm, with cataclastic fabrics, characterized by large variation in grain size and overall chaotic textures. Grain-size reduction by microcracking has produced subrounded to angular clasts of variably altered primary phases set in a fine-grained clast-clay matrix. Figure 6 shows development of shear zones (SZ) with progressive concentration of strain. Width of both photographs is $3.6 \mathrm{~mm}$. 